\title{
Optimizing wellness in chronic obstructive pulmonary disease
}

\author{
Roger S Goldstein MD FRCPC ${ }^{1}$, Dina Brooks BSc MSc PhD ${ }^{2}$, Gordon T Ford MD FRCPC ${ }^{3}$
}

\author{
Co-authors of sections \\ of the document \\ Doug Balson \\ Donna J Bleakney \\ Jean Bourbeau \\ Sonia Buist \\ Warren J Davidson \\ Richard Debigare
}

\author{
Sandra Delon \\ Neil D Eves \\ Mark Fitzgerald \\ Michael Fosbery Hindmarsh \\ Sharon Groeneveld \\ Kylie Hill \\ Kate Lorig \\ Sunita Mathur
}

\author{
Jennifer McNish \\ Louise McRae \\ Louise Morrin \\ Stefan Mustata \\ Diane Nault \\ Janet Philpott \\ Ronald Sigal \\ Don Sin
}

\author{
Tracy Smith \\ Nora Sobolov \\ Paula Stewart \\ Wan C Tan \\ William Vollmer \\ Sarah Wright
}

RS Goldstein, D Brooks, GT Ford. Optimizing wellness in chronic obstructive pulmonary disease. Can Respir J 2007;14(Suppl A):5A-22A.

Optimizing wellness in chronic obstructive pulmonary disease (COPD) is an emerging theme, in response to the substantial burden of COPD among Canadians. Population surveillance, from the Public Health Agency of Canada, as well as from international initiatives, such as the Burden of Obstructive Lung Disease (BOLD) study, has revealed the prevalence and regional disparities of a condition in which mortality, morbidity and health care resource use often reflect what was happening in the population more than 20 years previously. As COPD emerges to be an important women's health issue, it raises questions as to how female mortality from COPD can rise at double the rate of breast cancer, why the COPD patient population is still predominantly male and whether women experience breathlessness differently than men.

There is increasing awareness of the frequency and importance of assessing secondary impairments, such as muscle atrophy, an important prognostic indicator. The availability of pulmonary rehabilitation, despite its beneficial effects on exercise and quality of life, remains far behind the demand for services, a care gap unlikely to be filled by institutionally based programs. New models of chronic disease management require the health care system to proactively meet the needs of individuals with chronic conditions, rather than reacting to them through the acute care system. Such approaches occur best in partnership between health authorities and local municipalities. The present supplement includes several examples of this partnership, especially in Alberta and Saskatchewan. An increasing body of evidence supports the importance of exercise training, combined with selfmanagement, as a cornerstone of chronic disease management.

Key Words: COPD; Rehabilitation; Self-management; Surveillance

\section{Optimisation du mieux-être dans la broncho- pneumopathie chronique obstructive}

L'optimisation du mieux-être dans la bronchopneumopathie chronique obstructive (BPCO) est un sujet qui gagne de plus en plus de terrain en réaction au lourd fardeau qu'impose ce type de maladie au Canada. Des données sur la surveillance de la population, obtenues de l'Agence de santé publique du Canada ou tirées d'initiatives internationales comme l'étude Burden of Obstructive Lung Disease (BOLD), ont dévoilé la prévalence de la maladie et des disparités régionales dans lesquelles la mortalité, la morbidité et l'utilisation des ressources en santé reflétaient, dans bien des cas, la situation qui existait dans la population plus de 20 ans auparavant. Comme la BPCO apparait maintenant comme un important problème de santé chez les femmes, elle soulève les questions de savoir pourquoi la mortalité attribuable à la BPCO chez les femmes peut augmenter deux fois plus rapidement que celle attribuable au cancer du sein, pourquoi la population de patients atteints de BPCO se compose principalement d'hommes encore et si les femmes éprouvent la dyspnée d'une manière différente de celle des hommes. Il y a également une plus grande reconnaissance de la fréquence et de l'importance de l'évaluation des troubles secondaires comme l'amyotrophie, un important indicateur de pronostic. L'offre de services de réadaptation pulmonaire, malgré ses effets favorables sur la capacité d'effort et la qualité de vie, est loin de répondre à la demande, une faille dans les soins de santé peu susceptible d'être comblée par des programmes offerts dans les établissements. De nouveaux modèles de prise en charge des maladies chroniques exigent que les systèmes de soins répondent de manière proactive aux besoins des personnes concernées plutôt que de réagir à ceux-ci par la voie des systèmes de soins actifs. Ce genre d'approche fonctionne mieux dans des partenariats établis entre les autorités sanitaires et les municipalités locales. Le présent supplément présente plusieurs exemples de partenariat, établis tout particulièrement en Alberta et en Saskatchewan. De plus en plus de données probantes étayent l'importance de l'entraînement à l'effort, associé à la gestion de soi, comme pierre angulaire de la prise en charge des maladies chroniques.

volunteer organizations, academics, the public, researchers and educators.

The Public Health Agency of Canada conducts population surveillance on COPD and provides the information to this broad group of decision-makers. The presentation at 'Optimizing Wellness in COPD: The Fifth National Canadian COPD Alliance Conference' (November 17 to 19, 2006, Calgary, Alberta) summarized and interpreted the available data on COPD in Canada.

Having information about people living with chronic obstructive pulmonary disease (COPD), and about those with risk factors for this health problem, helps decision-makers make better choices about policies, programs and services. Decisionmakers include government policy people, health professionals,

\footnotetext{
${ }^{1}$ West Park Healthcare Centre, Toronto, Ontario; ${ }^{2}$ Department of Medicine and Physical Therapy, University of Toronto, Toronto, Ontario;

${ }^{3}$ Faculty of Medicine, University of Calgary, Calgary, Alberta

Correspondence and reprints: Dr Roger S Goldstein, West Park Healthcare Centre, 82 Buttonwood Avenue, Toronto, Ontario M6M 2J5.

Telephone 416-243-3631, fax 416-243-8947, e-mail rgoldstein@westpark.org
} 


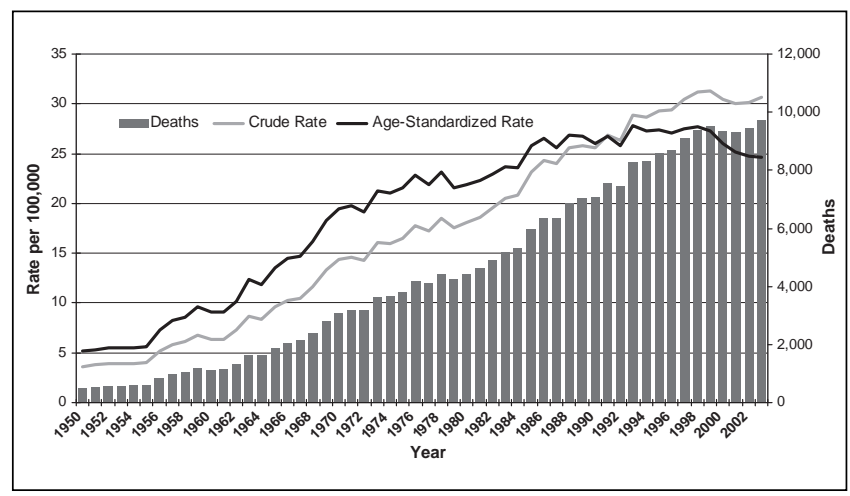

Figure 1) Chronic obstructive pulmonary disease mortality in Canada, 1950 to 2002. International Classification of Diseases codes J40 to J44 were used. Note that the coding schemes for this condition changed in 1968, 1978 and 2000, and this may influence trends. The standardized rate used 1991 Canadian population data. Reproduced with permission from the Centre for Chronic Disease Prevention and Control, Public Health Agency of Canada, using Vital Statistics Data from Statistics Canada 2006

\section{Who has COPD?}

- According to the Canadian Community Health Survey, in $2005,754,700$ adults $(329,500$ men [3.9\%] and 425,300 women [4.8\%]) over the age of 35 years $(4.4 \%$ of the population) reported having chronic bronchitis, emphysema or COPD.

- Among those over the age of 75 years, the proportion increased to almost one in 10 individuals (9.3\% [11.8\% of men and $7.5 \%$ of women]).

- The numbers of individuals reporting chronic bronchitis, emphysema or COPD have been similar since 2000.

- At younger than 75 years of age, women have a higher prevalence of COPD than men, but at 75 years and older, the prevalence is 1.5 times higher in men.

- The figures are probably underestimates because people delay going for diagnosis and treatment until the disease is well developed.

- The 2007 Statistics Canada Canadian Health Measure Survey will give better estimates of how common COPD is because it will test all participants over the age of 35 years with spirometry to measure lung function.

What progress is being made in reducing the risk of COPD?

- Cigarette smoking is the most important risk factor for COPD.

- According to the 2005 Canadian Community Health Survey, $18 \%$ of males aged 12 years and older reported smoking cigarettes daily, as did $15 \%$ of females.

- Among men aged 20 to 54 years, more than one in five ( $22 \%$ to $23 \%$ in each of the 10 -year age groups) reported smoking daily.

- The proportion of women aged 20 to 54 years who reported smoking daily was slightly lower (17\% to 20\%) but still high.
- It is encouraging that the proportion of young people who report smoking continues to decrease, but almost one in five teens aged 15 to 19 years (18\%) report smoking daily, as do more than one in four $(28 \%)$ of those aged 20 to 24 years.

- Among those who report having COPD, 33.6\% (32.6\% of men and $34.3 \%$ of women) report that they still smoke daily. For this population, stopping smoking is critical to prolonging their life.

\section{Are deaths from COPD changing?}

- Death from COPD usually comes many years after its onset. Therefore, mortality rates reflect what was happening in the population 15 to 20 years before, in terms of developing COPD.

- In 2003, there were 9700 deaths (5317 among men, 4383 among women) attributable to COPD in Canada. That was $4 \%$ of all deaths in Canada - a similar number to that from deaths attributable to diabetes, colorectal cancer and breast cancer (for women).

- The number of deaths due to COPD is likely much higher because pneumonia or heart or respiratory failure may be listed as the reason for death on the death certificate when COPD is the underlying condition.

- Death rates increase dramatically for individuals older than 75 years of age.

- Among individuals younger than 70 years, death rates for women are similar to those for men. Among those older than 75 years, the rates for men are more than twice those for women.

- The number of deaths due to COPD and the crude death rate (number of deaths divided by the number of people in the population) are increasing over time (Figure 1). The increase is due in part to an increase in the number of older people in the population. The age-standardized death rate for COPD, which adjusts for changes in the age structure of the population, is decreasing.

- The increase in the number of deaths is also due to an increase in deaths among women with COPD (Figure 2). It is expected that the number of deaths due to COPD will be higher for women than for men in the next few years.

How will health services be challenged by COPD in the future?

- In 2003, there were 64,589 hospitalizations (33,118 for men and 31,471 for women) in which COPD was considered the most responsible diagnosis for the stay in hospital (Figure 3). This comprises almost $3 \%$ of all hospitalizations - more than for stroke, more than for acute myocardial infarction among women, and only $20 \%$ less than for acute myocardial infarction among men.

- Hospitalization rates increase with age and are similar for men and women up to the age of 70 years. Over the age 


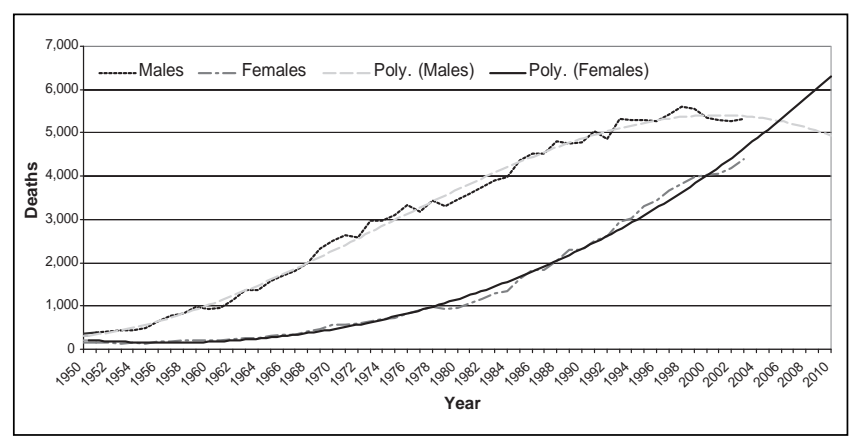

Figure 2) Number of deaths for chronic obstructive pulmonary disease by sex in Canada, 1950 to 2003 (projections to 2010). International Classification of Diseases codes J40 to J44 were used. Note that the coding schemes for this condition changed in 1968, 1978 and 2000, and this may influence trends. Reproduced with permission from the Centre for Chronic Disease Prevention and Control, Public Health Agency of Canada, using Vital Statistics Data from Statistics Canada 2006. Poly Polynomial regression

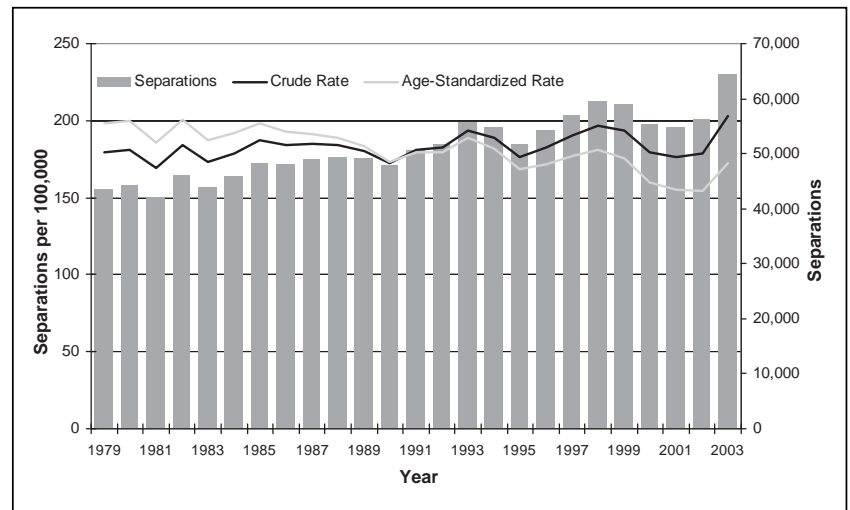

Figure 3) Chronic obstructive pulmonary disease hospital separations in Canada, 1979 to 2003. International Classification of Diseases codes J40 to J44 were used. Note that the coding schemes for this condition changed in 1968, 1978 and 2000, and this may influence trends. The standardized rate used 1991 Canadian population data. Before 1993, only the 10 Canadian provinces were included. Reproduced with permission from the Centre for Chronic Disease Prevention and Control, Public Health Agency of Canada, using Vital Statistics Data from Statistics Canada 2006

of 70 years, men have higher rates of hospitalization.

This difference between the sexes is similar to what was found with the death data.

- The number of hospitalizations is increasing due to higher rates of hospitalization among women over time and because the population continues to age (Figure 4).

\section{Interpretation of data}

Smoking prevention and cessation programs need to continue to focus on young people, but it is also important to consider what can be done to further encourage middle-aged and older adults to stop smoking. This group is at high risk for developing COPD both now and in the future. Programs for those living with COPD need to have an effective smoking cessation component for those who have not yet stopped smoking.

The picture of COPD is changing from a male-dominated disease. While death and hospitalization rates for men are decreasing, they are increasing for women. This results in an overall increase in the number of deaths and hospitalizations

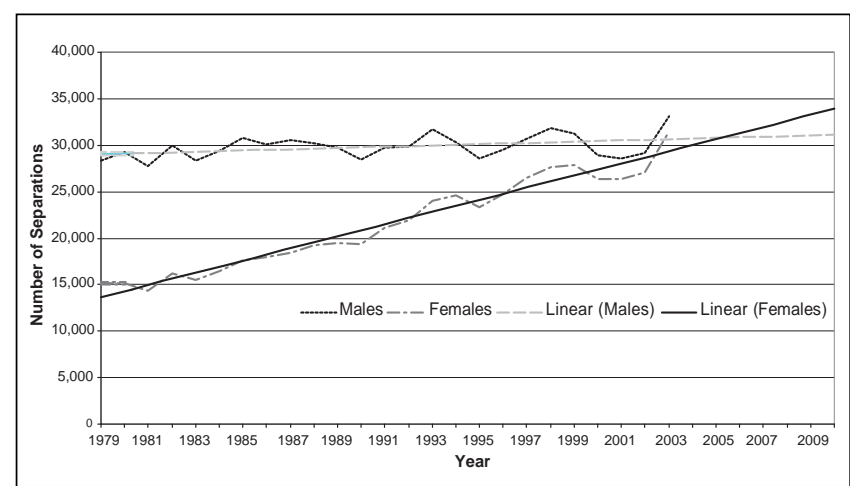

Figure 4) Chronic obstructive pulmonary disease hospitalizations by sex in Canada, 1979 to 2003 (projections to 2010). International Classification of Diseases codes J40 to J44 were used. Note that the coding schemes for this condition changed in 1968, 1978 and 2000, and this may influence trends. Before 1993, only the 10 Canadian provinces were included. Reproduced with permission from the Centre for Chronic Disease Prevention and Control, Public Health Agency of Canada, using Vital Statistics Data from Statistics Canada 2006

for COPD in Canada contributed by the aging population. The shift among the younger age groups to similar patterns of hospitalization and death rates in women and men will likely move through the older age groups over time.

The increase in hospitalizations and deaths is an indication of the increase in services now required to manage individuals living with COPD, and points to a continued increase in the near future. Women have unique needs, related to such things as living alone and their caretaker role within the family, that need to be addressed by COPD management programs.

\section{THE BURDEN OF OBSTRUCTIVE LUNG DISEASE (BOLD) STUDY IN VANCOUVER, CANADA - SAMPLING AND RECRUITMENT \\ Wan C Tan, Don Sin, Doug Balson, Mark Fitzgerald, William Vollmer, Sonia Buist}

Worldwide, the disease burden in COPD is high, yet awareness of COPD remains low in the health care community, in government and among the public (1). A major reason is the lack of information about the prevalence and the economic and social burden of COPD, which results in incomplete understanding of the real impact of the disease on quality of life and direct and indirect health care costs.

The Burden of Obstructive Lung Disease (BOLD) study (2) is an international initiative to collect population-based prevalence data throughout the world using a standardized protocol that includes the same data instruments, equipment, training, data collection, centralized quality control of spirometry performance and data management. The only item that is not identical for all centres is the sampling and recruitment method, which varies from the traditional epidemiological sampling approaches to the use of random digital dialing (RDD) for population sampling and recruitment (3).

\section{Methods}

In Vancouver, BC Stats was contracted to develop a random population-based sample of individuals for the BOLD study. Data collection for the Vancouver BOLD study was initiated in August 2005 and completed in April 2006. 
TABLE 1

Age-sex distribution of the population sampled in the Vancouver Burden of Obstructive Lung Disease (BOLD) study

\begin{tabular}{lccc}
\hline Age group & Male & Female & Total \\
\hline 18 to 39 years & $115,684(51 \%)^{\star}$ & $112,674(49 \%)^{*}$ & $228,359(46 \%)^{\ddagger}$ \\
$40+$ years & $129,184(48 \%)^{\dagger}$ & $140,206(52 \%)^{\dagger}$ & $269,390(54 \%)^{\ddagger}$ \\
Total & $244,868(49 \%)$ & $252,880(51 \%)$ & $497,748(100 \%)$ \\
\hline
\end{tabular}

*Sex proportion in the group aged 18 to 39 years; ${ }^{\dagger}$ Sex proportion in the group aged 40 years and older; ${ }^{\ddagger}$ Age distribution of adults aged 18 years and older

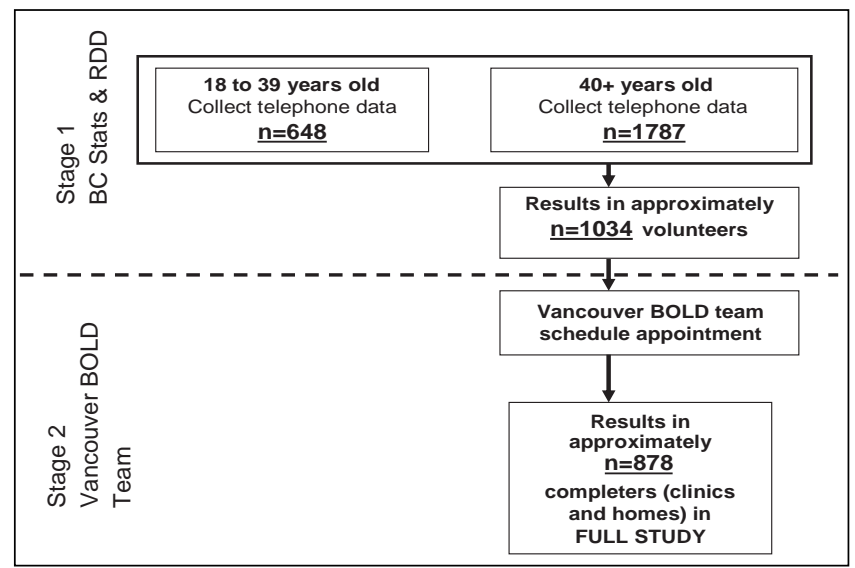

Figure 5) Overview of the sampling process used in the Vancouver Burden of Obstructive Lung Disease (BOLD) study. BC Stats was contracted to develop the random sample and the use of random digit dialing $(R D D)$ to recruit the subjects. Volunteers were people aged 40 years and older who agreed to do the full BOLD study; completers were the volunteers who completed the full study

Target population: The target population consisted of noninstitutionalized adults aged 18 years and older who reside in the Vancouver Health Service Delivery Area (HSDA) of the Vancouver Coastal Health Authority. This included the following local health areas of Vancouver: city centre, downtown eastside, northeast, westside, midtown and south. The age-sex distribution of the Vancouver HSDA is provided in Table 1.

The targeted sample size was 600 individuals aged 18 to 39 years and 1000 individuals aged 40 years and older.

Sampling design: Sampling and recruitment consisted of two stages: stage 1 was done by BC Stats, and stage 2 was performed by the Vancouver BOLD study team (Figure 5). In the first stage, BC Stats drew the sample and performed the initial recruitment. RDD was used to identify and recruit participants. The sampling frame covered all individuals in the study area (the Vancouver HSDA), excluding residents without land-line telephones and residents of institutions. Overall, these exclusions amounted to less than 3\% of the total population of British Columbia.

The sample phone numbers used by BC Stats were supplied by ASDE Inc (Gatineau, Quebec) (3). The ASDE Inc methodology links phone numbers to defined geographical regions to assure good geographical representation, high coverage probability and a known probability of being selected for all individuals. From this sampling frame, phone numbers for calling were selected using simple random sampling. Only one participant was ultimately recruited from any given household.

To assure high response rates, contact phone numbers were selected in batches, and each batch was fully worked before a
TABLE 2

Comparison of socioeconomic status, sex and ethnic distribution between the Vancouver Burden of Obstructive Lung Disease (BOLD) study sample and the Vancouver population

\begin{tabular}{|c|c|c|c|c|c|}
\hline & $\begin{array}{l}18 \text { to } 39 \\
\text { years* } \\
(n=648)\end{array}$ & $\begin{array}{c}\text { 40+ years, } \\
\text { all* } \\
(n=1787)\end{array}$ & $\begin{array}{c}40+\text { years, } \\
\text { completers } \\
(n=878)\end{array}$ & $\begin{array}{l}\text { Vancouver } \\
\text { population }\end{array}$ & $P^{\ddagger}$ \\
\hline \multicolumn{6}{|c|}{ Socioeconomic status } \\
\hline $\begin{array}{l}\text { Lowest } \\
\qquad(<\$ 20,000)\end{array}$ & $23 \%$ & $25 \%$ & $20 \%$ & $16 \%$ & 1 \\
\hline $\begin{array}{l}\text { Lower }+ \\
\text { intermediate } \\
(\$ 20,000-\$ 80,000)\end{array}$ & $49 \%$ & $46 \%$ & $47 \%$ & $56 \%$ & \\
\hline $\begin{array}{l}\text { Highest } \\
\qquad(>\$ 80,000)\end{array}$ & $28 \%$ & $29 \%$ & $33 \%$ & $28 \%$ & \\
\hline \multicolumn{6}{|l|}{ Sex } \\
\hline Male & $48 \%$ & $41 \%$ & $42 \%$ & $48 \%$ & 1 \\
\hline Female & $52 \%$ & $59 \%$ & $58 \%$ & $52 \%$ & \\
\hline \multicolumn{6}{|l|}{ Ethnicity } \\
\hline Caucasian & & & $81 \%$ & $52 \% \quad P$ & $P<0.001$ \\
\hline Minorities & & & $19 \%$ & $48 \%$ & \\
\hline
\end{tabular}

${ }^{*}$ Recruited subjects who answered telephone survey minimal data question-

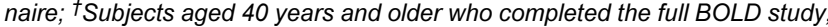
${ }^{\ddagger}$ Comparison between subjects aged 40 years and older who completed the full BOLD study and the Vancouver population

new batch was selected. A minimum of 10 attempts were made to contact each household, and up to six call attempts were made to convert 'soft refusals'.

Once a household was contacted, the 'next birthday' technique (3) was used to select the target participant. In this technique, the interviewer asks to speak with the person in the household (aged 18 years or older) who has the next birthday. The interview was conducted in English or Chinese (the predominant minority language).

Calling continued until the telephone survey minimal data questionnaire was completed by at least 600 individuals aged 18 to 39 years and until 1000 individuals aged 40 years or older agreed to complete the full protocol. This list of volunteers was then given to the Vancouver BOLD study team for further follow-up. Minimal data questionnaires from all contacted individuals aged 40 years and older, regardless of their willingness to participate in the full survey, were also collected and given to the Vancouver BOLD study team for data entry.

Full study recruitment: Once individuals agreed to participate in the full BOLD study protocol, they were contacted by the Vancouver BOLD study team for scheduling for the full study, which occurred at St Paul's Hospital's respiratory research laboratory or, if requested, in the subjects' homes.

For the full study visit, each subject was interviewed using a set of standardized detailed questionnaires on demographics, potential risk factors (including biomass fuel and occupational exposure), comorbid illnesses, smoking habits, respiratory symptoms and quality of life. In addition, spirometric measurements were obtained using a portable spirometer (EasyOne; ndd AG, Switzerland) before and 20 min after the administration of $200 \mu \mathrm{g}$ of inhaled albuterol/salbutamol.

Analysis: The demographic, socioeconomic and ethnic characteristics of the respondents from the population-based random 
sample were compared with those of the sampling frame using the $\chi^{2}$ test.

Results of sampling and recruitment

In the first phase of recruitment, age eligibility was established in 2434 of 9475 people contacted. There were 648 subjects aged 18 to 39 years and 1786 subjects aged 40 years and older who provided minimal data over the phone. Of the latter group, 1033 individuals (58\%) agreed to participate in the full study (Figure 5), while 878 of 1033 volunteers (85\%) completed the full study. There was no significant difference in sex distribution between the responders and nonresponders (ie, active refusers and those with partial data) who were contacted.

The final full study sample was demographically similar in terms of sex proportion and socioeconomic distribution to the Vancouver population sampled, although there were more Caucasians in the final full study sample than in the general population (Table 2).

\section{Discussion}

RDD is a familiar method for conducting telephone surveys in the population $(4,5)$. In the Vancouver BOLD study, the random sample thus developed was representative of the population from which it was drawn, with the exception of ethnic representation due to different cultural habits in volunteerism. RDD was a valid sampling method for the population-based, epidemiological BOLD study.

ACKNOWLEDGEMENTS: The authors thank the staff of the iCapture centre and the Pacific Lung Centre, St Paul's Hospital, Vancouver, and the BC Lung Association for their logistic assistance with the project. The authors are grateful to AstraZeneca (Canada), Boehringer Ingelheim (Canada), Pfizer (Canada) and GlaxoSmithKline (Canada) for funding the project with an unrestricted educational grant.

\section{REFERENCES}

1. Lenfant C, Khaltaev N. Global Initiative for Chronic Obstructive Lung Disease. Global Strategy for the Diagnosis, Management, and Prevention of Chronic Obstructive Pulmonary Disease. National Heart, Lung \& Blood Institute/World Health Organization Workshop Report. NIH Publication No. 2701. Washington: US Department of Health \& Human Services, National Heart, Lung \& Blood Institute, 2001:1-100.

2. Buist AS, Vollmer WM, Sullivan SD, et al. The Burden of Obstructive Lung Disease Initiative (BOLD): Rationale and design. COPD 2005;2:277-83.

3. Waksberg J. Sampling methods for random digit dialing. JASA 1978;73:40-6.

4. Slep AM, Heyman RE, Williams MC, Van Dyke CE, O'Leary SG. Using random telephone sampling to recruit generalizable samples for family violence studies. J Fam Psychol 2006;20:680-9.

5. Perneger TV, Myers TL, Klag MJ, Whelton PK. Effectiveness of the Waksberg telephone sampling method for the selection of population controls. Am J Epidemiol 1993;138:574-84.

\section{PULMONARY REHABILITATION IN 2006: WHAT WORKS, WHAT DOESN'T AND WHAT IS PRESENTLY BEING DONE IN CANADA Dina Brooks, Kylie Hill, Roger Goldstein}

Pulmonary rehabilitation (PR) "is an evidence based, multidisciplinary and comprehensive intervention for patients with chronic respiratory disease who are symptomatic and often have decreased daily life activities" (1). The ultimate goal of
TABLE 3

Practice guidelines from the American Thoracic Society/European Respiratory Society Task Force

\begin{tabular}{|c|c|}
\hline Exercise training & $\begin{array}{l}\text { A minimum of } 20 \text { sessions, at least three times per } \\
\text { week, to achieve physiological benefits } \\
\text { High-intensity exercise produces greater physiological } \\
\text { benefits and should be encouraged } \\
\text { Low-intensity training and interval training are effective } \\
\text { for those at a lower level of functioning } \\
\text { Pulmonary rehabilitation should include both upper } \\
\text { and lower extremities, and a combination of } \\
\text { endurance and strength }\end{array}$ \\
\hline Education & $\begin{array}{l}\text { Should emphasize self-management, including } \\
\text { an action plan, with importance placed on the } \\
\text { transfer of information into the home } \\
\text { In selected patients, consider education regarding } \\
\text { breathing strategies and bronchial hygiene }\end{array}$ \\
\hline $\begin{array}{l}\text { Psychological } \\
\text { and social } \\
\text { considerations }\end{array}$ & $\begin{array}{l}\text { Depression and anxiety should be considered in } \\
\text { individuals with chronic obstructive pulmonary disease } \\
\text { A patient support system is an important component } \\
\text { of rehabilitation }\end{array}$ \\
\hline Nutrition & $\begin{array}{l}\text { Abnormal body weight should be managed with caloric, } \\
\text { physiological, pharmacological or combination therapies }\end{array}$ \\
\hline $\begin{array}{l}\text { Oxygen } \\
\text { supplementation }\end{array}$ & $\begin{array}{l}\text { Oxygen during exercise may enable higher training } \\
\text { intensities, but its long-term impact is not known }\end{array}$ \\
\hline $\begin{array}{l}\text { Noninvasive } \\
\text { positive pressure } \\
\text { ventilation }\end{array}$ & $\begin{array}{l}\text { Ongoing noninvasive positive pressure ventilation } \\
\text { may be useful in some patients, with demonstrated } \\
\text { benefits }\end{array}$ \\
\hline $\begin{array}{l}\text { Inspiratory muscle } \\
\text { training }\end{array}$ & $\begin{array}{l}\text { May be useful in some patients, as an adjunct to } \\
\text { pulmonary rehabilitation }\end{array}$ \\
\hline $\begin{array}{l}\text { Neuromuscular } \\
\text { electrical } \\
\text { stimulation }\end{array}$ & $\begin{array}{l}\text { Useful in patients with severe disease who are } \\
\text { bed-bound or suffering from extreme skeletal } \\
\text { muscle weakness }\end{array}$ \\
\hline
\end{tabular}

Data from reference 1

PR is to minimize impairment, decrease activity limitations and promote autonomy for individuals with respiratory disease (1). The objectives of the present section are to summarize the evidence-based statements on PR and report the common characteristics of PR programs in Canada.

\section{Evidence-based statements on PR}

According to the latest evidence-based statement (1), PR should include patient assessment, exercise training, education and psychosocial support. The European Respiratory Society and the American Thoracic Society have provided guidelines (1) for exercise, education, psychosocial support, nutrition, oxygen supplementation, noninvasive positive pressure ventilation, inspiratory muscle training and neuromuscular electrical stimulation (Table 3).

\section{State of PR in Canada}

In 1999, the results of the first national survey to provide information on the structure, content and organization of PR in Canada were published (2). It was noted that PR was often unavailable to many of those who could potentially benefit from it, with only $0.5 \%$ of patients diagnosed with respiratory disease being able to access a program. A subsequent recent survey (2), in 2005, noted a similar shortfall, with only $1.2 \%$ of patients being able to access a program. 
TABLE 4

Program characteristics

\begin{tabular}{|c|c|c|c|c|c|c|}
\hline & $\underset{(n=10)}{\text { Inpatient }}$ & $\begin{array}{l}\text { Outpatient } \\
(n=56)\end{array}$ & 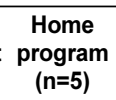 & $\begin{array}{c}\text { Maintenance } \\
\quad(\mathrm{n}=\mathbf{2 2})\end{array}$ & $\begin{array}{l}\text { Other* } \\
(n=5)\end{array}$ & $\begin{array}{c}\text { All } \\
(n=98)\end{array}$ \\
\hline Patients $^{\dagger}$ & $8.1 \pm 12$ & $14.4 \pm 15$ & $8.3 \pm 8.5$ & $29.2 \pm 24.1$ & $9.3 \pm 0.6$ & $16.4 \pm 17.4$ \\
\hline Days/week ${ }^{\dagger}$ & $5.5 \pm 1.6$ & $2.2 \pm 0.8$ & $2.0 \pm 1.0$ & $2.2 \pm 1.7$ & $2.3 \pm 1.0$ & $2.6 \pm 1.5$ \\
\hline $\begin{array}{l}\text { Hours/ } \\
\text { session }\end{array}$ & $1.8 \pm 1.5$ & $2.1 \pm 1.1$ & $2.0 \pm 1.0$ & $1.5 \pm 0.5$ & $1.6 \pm 0.5$ & $1.9 \pm 1.0$ \\
\hline $\begin{array}{l}\text { Duration }{ }^{\dagger} \\
\text { (weeks) }\end{array}$ & $3.9 \pm 2.2$ & $9.1 \pm 5.6$ & $9.0 \pm 2.5$ & $13.3 \pm 5.9$ & $8.3 \pm 4.0$ & $8.9 \pm 5.5$ \\
\hline $\begin{array}{l}\text { National } \\
\text { rehabilitation } \\
\text { capacity } \ddagger\end{array}$ & $\begin{array}{l}911 \\
\text { n }\end{array}$ & 5101 & 455 & 2004 & 455 & 8927 \\
\hline
\end{tabular}

*Three were described as booster, one as by individual appointment and one as a research program; ${ }^{\dagger}$ Mean $\pm S D ;{ }^{\ddagger}$ The national rehabilitation capacity was calculated by summing the program estimates, derived from multiplying the number of patients enrolled in a program by the number of program rotations available in a year. Reproduced from reference 3

Of the 98 PR programs identified in Canada in 2005, most (57\%) were outpatient (patients travelled regularly into a health care facility from home), and $10 \%$ were inpatient (patients admitted to a health care facility for a period of time). The program characteristics are summarized in Table 4. COPD was the most frequently identified diagnostic category of patients participating in PR (90\% of patients in both inpatient and outpatient programs). Asthma was the next most frequently reported diagnostic category (less than $5 \%$ of patients). Considerable variability was reported in the attendance of individuals with all other respiratory diseases (3).

The main program components included supervised lower extremity strength $(77 \%)$, cycle $(72 \%)$ and treadmill (70\%) training; education (75\%); breathing retraining $(68 \%)$; and upper extremity strength training $(60 \%)$. The most common education topics were medication use, signs of infection, energy conservation, pulmonary anatomy and physiology, relaxation, panic control and nutrition. Education topics pertaining to end-of-life decision-making, sleep hygiene and advanced care planning were rarely included (3).

Physical therapists, dietitians, respiratory therapists and respirologists were the most commonly identified health care providers. Respirologists were the most frequent medical directors $(63 \%)$, followed by general practitioners $(14 \%)$, and internists or physiatrists (23\%).

The most frequently used outcome measures were the $6 \mathrm{~min}$ walk test, in $70 \%$ and $90 \%$ of inpatients and outpatients, respectively, and a disease-specific health-related quality of life questionnaire (Chronic Respiratory Questionnaire or St George's Respiratory Questionnaire), in $40 \%$ and $72 \%$ of inpatients and outpatients, respectively (3).

\section{Comparison of present state to the evidence}

The core elements of PR - exercise training, education, selfmanagement, and psychological and social support (1) - were included in most of the programs surveyed (3). Breathing exercises were also included in the majority of programs, despite the lack of evidence to support this intervention.

A disappointing number of PR programs included objective outcome measures, such as standardized walk tests $(70 \%$ of inpatient programs) and disease-specific health-related quality of life ( $42 \%$ of inpatient programs). Limited resources may explain this low number of programs that used a standardized measure. The use of support groups and telephone support post-PR in $20 \%$ to $30 \%$ of the programs is an encouraging new development not observed in the earlier survey. Such strategies may promote the maintenance of benefits demonstrated on completion of a PR program.

In summary, despite the strong evidence to support the role of PR, such therapy is available in Canada to only a small percentage of patients with COPD. A United Kingdom survey (4) noted a similar shortfall and reported that less than $1 \%$ of patients with COPD received PR. Programs include the components supported by evidence, although greater attention is needed to ensure that all practice guidelines are considered.

ACKNOWLEDGEMENTS: The present section was supported by the Ontario Lung Association and West Park Healthcare Centre Foundation. Dr Brooks was supported by a Canadian Institutes of Health Research New Investigator Award.

\section{REFERENCES}

1. Nici L, Donner C, Wouters E, et al; ATS/ERS Pulmonary Rehabilitation Writing Committee. American Thoracic Society/European Respiratory Society statement on pulmonary rehabilitation. Am J Respir Crit Care Med 2006;173:1390-413

2. Brooks D, Lacasse Y, Goldstein RS. Pulmonary rehabilitation programs in Canada: National survey. Can Respir J 1999;6:55-63.

3. Brooks D, Sottana R, Bell B, et al. Characterization of pulmonary rehabilitation programs in Canada in 2005. Can Respir J 2007;14:87-92.

4. Yohannes AM, Connolly MJ. Pulmonary rehabilitation programmes in the UK: A national representative survey. Clin Rehabil 2004;18:444-9.

\section{EXERCISE AS MEDICINE FOR PATIENTS WITH CHRONIC DISEASE}

Neil D Eves, Stefan Mustata, Ronald Sigal, Warren J Davidson, Sharon Groeneveld, Gordon T Ford

Exercise training is an established cornerstone of chronic disease management (CDM) that, when combined with behaviour change and improved patient self-management, can lead to successful disease modification and health promotion. An increasing body of evidence supports the essential role of physical activity for the promotion of health (Table 5) and for the prevention of many different conditions (1). However, physical activity alone is insufficient to 'optimally' modify chronic disease states. Support is growing for the role of prescriptive exercise to maximize the health benefits from exercise rehabilitation programs (Table 6), such as those for patients with COPD (2).

Given that prescriptive exercise can modify chronic disease outcomes, exercise can be considered a 'medicine', with a doseresponse curve similar to that of any pharmaceutical intervention (Figure 6) (3). Similar to any drug, exercise must be modified over time as the body adjusts to the exercise stress, and prescription must be altered accordingly to continually enhance or maintain its benefit. As with drugs, exercise may also have side effects if prescribed at too great an intensity or duration. These include cardiovascular events, severe dyspnea, musculoskeletal injury or excessive fatigue. As a result, it is important to assess each patient properly and to prescribe exercise at an appropriate level for each individual.

Exercise training can improve health status, functional capacity, dyspnea, skeletal muscle function and potentially 
TABLE 5

Known benefits of physical activity for health promotion

Improved functional capacity

Reduced stress

Improved mood

Improved sleep

Improved self-efficacy

Improved self-image

TABLE 6

Known benefits of prescriptive exercise for disease modification

\begin{tabular}{ll}
\hline Disorder & Benefit \\
\hline Chronic obstructive & Decreased dyspnea \\
pulmonary disease & Increased exercise capacity \\
Decreased body mass index & Decreased fat mass \\
Hypertension & Decreased blood pressure \\
Diabetes (types 1 and 2) & $\begin{array}{l}\text { Decreased use of antihypertensive medications } \\
\text { Improved glycemic control }\end{array}$ \\
Dyslipidemia & Decreased total cholesterol \\
Cardiovascular disease & $\begin{array}{l}\text { Increased high-density lipoprotein cholesterol } \\
\text { Decreased all-cause mortality }\end{array}$ \\
Renal disease & Decreased cardiac mortality \\
& Decreased pulse pressure \\
Congestive heart failure & Decreased arterial stiffness \\
& Increased stroke volume \\
& Decreased peripheral resistance
\end{tabular}

survival (4). Furthermore, health care utilization has been shown to decrease following a successful rehabilitation program (5). To induce the maximal benefit on clinically important outcomes from exercise, it is important to identify the underlying exercise limitation(s) and to prescribe exercise on an individual basis as would be done for any pharmaceutical intervention $(6-8)$. The exercise prescription should be continually reassessed and modified over time to ensure that the long-term benefits of exercise are maintained over a lifetime, not just the immediate postrehabilitation period.

In patients with COPD, exercise training improves exercise tolerance and reduces ventilation, dyspnea, leg fatigue and metabolic acidosis $(4,9)$. Even though exercise of any nature can cause physiological adaptation, it is also evident that prescribed exercise, usually of moderate to high intensity, can have greater effects. Casaburi et al (10) found that having subjects exercise five days per week for eight weeks, for 45 min per day, at a high intensity was more effective for improving blood lactate and ventilation than longer duration, lower intensity exercise, even though the total work was equalized. Furthermore, endurance time for constant work exercise, at high or low intensity, increased more among those in the highintensity training group than among those training at a low work rate. Vallet et al (2) also reported that an individualized training program was more effective than a standardized exercise prescription for improving symptom-limited oxygen uptake, reducing ventilatory demand and reducing blood lactate, supporting the need for individualized exercise prescriptions to optimize physiological outcomes (2).

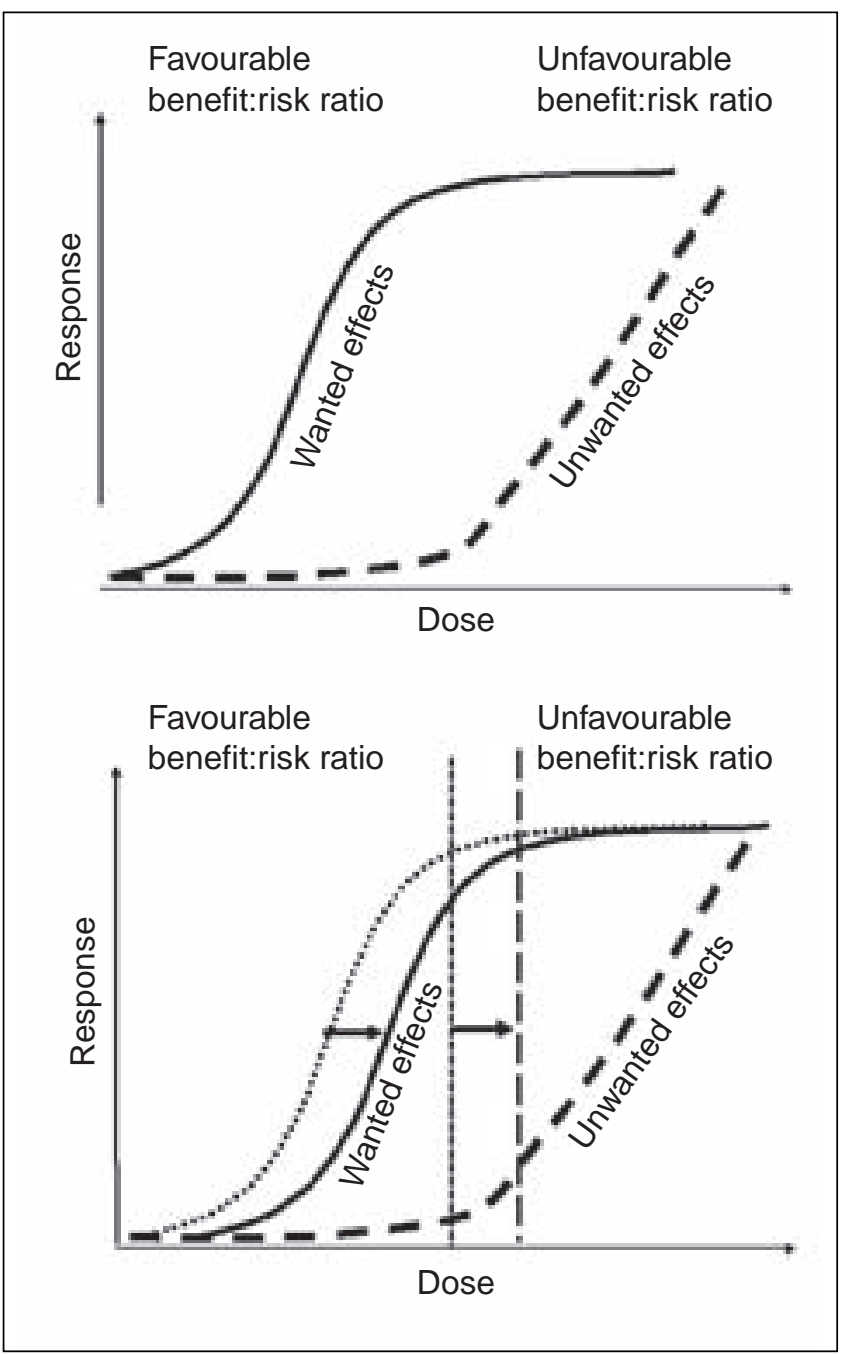

Figure 6) Dose-response curve (hypothesis). Upper panel The exercise response is shown as the dose (intensity) of exercise increases, within the favourable zone. A further increase in dose may move the response into the unfavourable zone, resulting in unwanted effects such as angina, musculoskeletal injury or excessive fatigue. Lower panel The physiological adaptation to exercise training requires an increased dose of exercise to achieve the same favourable effects

To further optimize the benefits of exercise in COPD, it is also important to maximize pharmaceutical therapy before and during rehabilitation. Casaburi et al (11) recently demonstrated that taking an inhaled, long-acting anticholinergic bronchodilator once daily for five weeks before and then throughout a PR program produced greater clinically meaningful improvements in dyspnea and health status than did the same PR program alone. Improvements in subjects in the combined bronchodilator and exercise group were sustained for three months following completion of the program, in contrast to a slight decline among subjects in the control group. These findings support the use of nonpharmacological and pharmacological approaches for improving and maintaining the physiological adaptations to exercise training.

In summary, considerable evidence now supports the concept that exercise is 'medicine' for patients with chronic disease, which requires careful prescription, continuous monitoring and adjustment. We must continue to strive to understand the underlying pathophysiological mechanisms of 
exercise and the best techniques to optimize its use both for short-term and for lifelong benefits. Additionally, we need to better understand the best strategies for improving exercise prescription, ensuring lifelong patient adherence following the initial phase of supervised training and combining exercise with a variety of other emerging therapies (12).

\section{REFERENCES}

1. Lees SJ, Booth FW. Sedentary death syndrome. Can J Appl Physiol 2004;29:447-60; discussion 444-6.

2. Vallet G, Ahmaidi S, Serres I, et al. Comparison of two training programmes in chronic airway limitation patients: Standardized versus individualized protocols. Eur Respir J 1997;10:114-22.

3. Pedersen S, O'Byrne P. A comparison of the efficacy and safety of inhaled corticosteroids in asthma. Allergy 1997;52(39 Suppl):1-34.

4. Nici L, Donner C, Wouters E, et al; ATS/ERS Pulmonary

Rehabilitation Writing Committee. American Thoracic Society/European Respiratory Society statement on pulmonary rehabilitation. Am J Respir Crit Care Med 2006;173:1390-413.

5. Bourbeau J, Julien M, Maltais F, et al; Chronic Obstructive Pulmonary Disease axis of the Respiratory Network Fonds de la Recherche en Sante du Quebec. Reduction of hospital utilization in patients with chronic obstructive pulmonary disease: A diseasespecific self-management intervention. Arch Intern Med 2003;163:585-91.

6. Mustata S, Chan C, Lai V, Miller JA. Impact of an exercise program on arterial stiffness and insulin resistance in hemodialysis patients. J Am Soc Nephrol 2004;15:2713-8.

7. Pedersen BK, Saltin B. Evidence for prescribing exercise as therapy in chronic disease. Scand J Med Sci Sports 2006;16(Suppl 1):3-63.

8. Sigal RJ, Kenny G, Phillips P, et al. Effects of resistance exercise, aerobic exercise and their combination on glycemic control in type 2 diabetes: The Diabetes Aerobic and Resistance Exercise (DARE) clinical trial. Diabetes 2005;54:A91.

9. Troosters T, Casaburi R, Gosselink R, Decramer M. Pulmonary rehabilitation in chronic obstructive pulmonary disease. Am J Respir Crit Care Med 2005;172:19-38.

10. Casaburi R, Patessio A, Ioli F, Zanaboni S, Donner CF, Wasserman K. Reductions in exercise lactic acidosis and ventilation as a result of exercise training in patients with obstructive lung disease. Am Rev Respir Dis 1991;143:9-18.

11. Casaburi R, Kukafka D, Cooper CB, Witek TJ Jr, Kesten S. Improvement in exercise tolerance with the combination of tiotropium and pulmonary rehabilitation in patients with COPD. Chest 2005;127:809-17.

12. Eves ND, Petersen SR, Haykowsky MJ, Wong EY, Jones RL. Heliumhyperoxia, exercise, and respiratory mechanics in chronic obstructive pulmonary disease. Am J Respir Crit Care Med 2006;174:763-71.

\section{PATHOGENESIS OF MUSCLE ATROPHY IN PEOPLE WITH COPD}

\section{Sunita Mathur, Richard Debigare}

Muscle atrophy is the loss of muscle mass. It may be due to a variety of contributing factors. Sarcopenia is the term used to describe the age-related decline in muscle size and strength, whereas cachexia refers to a loss of body mass, including muscle mass, as a result of a high resting metabolic rate and systemic inflammation $(1,2)$. It is estimated that approximately $26 \%$ of people with COPD have a low fat-free mass, and these people may have either a low or a normal body mass index $(3,4)$.

\section{Pathogenesis of muscle atrophy in COPD}

The amount of muscle tissue (ie, the protein content) in an individual is the result of a subtle balance between protein synthesis and breakdown (Figure 7). There is general agreement that people with COPD experience an increased protein turnover $(5,6)$. One of the prevailing mechanisms whereby muscle proteolysis occurs is through the activation of the ubiquitin-proteasome

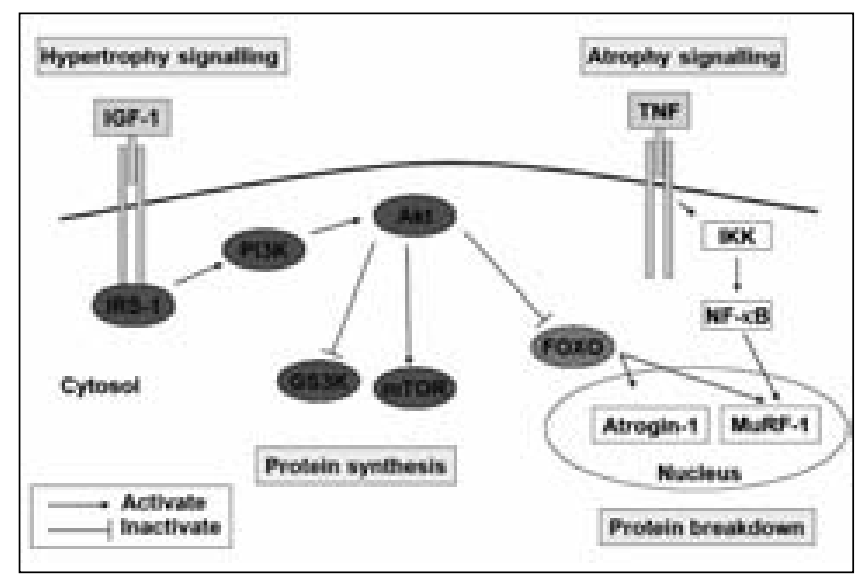

Figure 7) Hypertrophy and atrophy signalling in skeletal muscle cells. Akt Protein kinase B; FOXO Forkhead box O; GS3K Glycogen synthase kinase; IGF-1 Insulin-like growth factor-1; IKK IkappaB kinase; IRS-1 Insulin receptor substrate-1; mTOR Mammalian target of rapamycin; MuRF-1 Muscle ring finger-1; NF-KB Nuclear factor kappaB; PI3K Phosphatidylinisitol-3 kinase; TNF Tumour necrosis factor

(Ub-P'some) pathway, an ATP-dependant proteolytic system that degrades cellular and membrane proteins (7). Muscle ring finger-1 (MuRF-1) (8) and atrophy gene-1 (atrogin-1) (9), also known as muscle atrophy F-box (8), are two muscle-specific components of the Ub-P'some system. Recent reports $(8,9)$ noted an increase in the messenger RNA (mRNA) content for both atrogin-1 and MuRF-1 in the peripheral muscle of emaciated patients with COPD, compared with that in age-matched control subjects. In addition, a significant elevation in forkhead box $\mathrm{O}$ mRNA expression was also noted (Doucet et al, unpublished data). Forkhead box $\mathrm{O}-1$ is a transcription factor involved in the induction of atrogin-1 and MuRF-1 $(10,11)$. Taken together, these observations support the notion that proteolysis in the peripheral muscle of individuals with COPD occurs through the Ub-P'some system.

Signals suspected of triggering muscle atrophy in people with COPD are numerous and still under intense investigation. Among them, inflammation, low levels of anabolic hormones and oxidative stress have received substantial attention. The potential relationship among inflammation, oxidative stress and the Ub-P'some system is attractive because both proinflammatory cytokines and oxidants can induce muscle atrophy and inhibit myogenic differentiation $(12,13)$. Hypoxia may also be involved in the muscle phenotype changes in COPD (14). Current investigations (Caron et al, unpublished data) have shown an increased expression in atrogin-1 mRNA along with an elevation in the activity of the proteasome in myotubes exposed to a hypoxic atmosphere, supporting the role of hypoxia in inducing muscle atrophy. Because muscle mass homeostasis is dependant on several intricate regulating pathways, it is unlikely that disturbances in one single component of this complex system will entirely explain the wasting process (15). Therefore, research is needed to examine different aspects of these pathways.

\section{Assessment of muscle atrophy in people with COPD}

The assessment of muscle mass in people with COPD is becoming a more common practice in clinical and research settings. Assessment techniques range from simple anthropometric measurements, which can be easily applied in the clinical setting, 


\section{TABLE 7}

Summary of methods used to assess muscle mass in people with chronic obstructive pulmonary disease (COPD)

\begin{tabular}{|c|c|c|c|}
\hline Instrument & Measure obtained & Advantages & Disadvantages \\
\hline $\begin{array}{l}\text { Anthropometric measures } \\
\text { (skinfold, limb circumference) (19) }\end{array}$ & Muscle CSA & $\begin{array}{l}\text { Easily applicable to clinical setting } \\
\text { Inexpensive } \\
\text { Little training required }\end{array}$ & $\begin{array}{l}\text { Equations developed in young adult population } \\
\text { Tend to overestimate in COPD }\end{array}$ \\
\hline $\begin{array}{l}\text { Bioelectrical impedance analysis } \\
(20,21)\end{array}$ & $\begin{array}{l}\text { Fat-free mass } \\
\text { Fat mass }\end{array}$ & $\begin{array}{l}\text { Inexpensive } \\
\text { Easy to apply in clinical setting }\end{array}$ & $\begin{array}{l}\text { Two-compartment model of the body } \\
\text { Dependent on hydration level } \\
\text { Many assumptions behind reference equations }\end{array}$ \\
\hline $\begin{array}{l}\text { Dual-energy x-ray } \\
\text { absorptiometry (22) }\end{array}$ & $\begin{array}{l}\text { Fat-free mass } \\
\text { Fat mass } \\
\text { Bone mineral density }\end{array}$ & $\begin{array}{l}\text { Differentiates limbs from trunk } \\
\text { Provides measure of bone mineral density } \\
\text { Available in many hospitals }\end{array}$ & $\begin{array}{l}\text { Expensive } \\
\text { Technical training required } \\
\text { Exposure to a low dose of radiation }\end{array}$ \\
\hline Computed tomography (16) & Muscle CSA & $\begin{array}{l}\text { Specific measure of individual muscle CSA } \\
\text { Can assess muscle composition (inter- and } \\
\text { intramuscular fat) }\end{array}$ & $\begin{array}{l}\text { Exposure to radiation } \\
\text { Expensive } \\
\text { Limited availability } \\
\text { Technician required }\end{array}$ \\
\hline Magnetic resonance imaging (23) & Muscle CSA or volume & $\begin{array}{l}\text { Same as computed tomography; however, } \\
\text { no exposure to radiation, so multiple } \\
\text { images can be obtained }\end{array}$ & $\begin{array}{l}\text { Expensive } \\
\text { Limited availability } \\
\text { Technician required }\end{array}$ \\
\hline
\end{tabular}

References indicate studies that have used the instrument in people with COPD. CSA Cross-sectional area

to expensive radiological instruments requiring technical expertise. Many of these measures have been used among people with COPD, and the advantages and disadvantages of each are summarized in Table 7.

Consequences of muscle atrophy

In people with COPD, muscle atrophy is correlated with muscle weakness (16) and reduced exercise capacity (17). In the elderly, muscle atrophy is associated with poor mobility, which can further lead to a loss of independence (18). However, the relationship between muscle mass and mobility has not been specifically examined in people with COPD.

Muscle mass has also been used as a prognostic indicator in people with COPD. Marquis et al (19) reported that the mid-thigh cross-sectional area was superior to body mass index as a predictor of mortality in COPD. More recently, Vestbo et al (4) showed that people with COPD and a fat-free mass index in the lowest 10th percentile of the general population had a greater mortality risk, even if their body mass index was within the normal range.

\section{Conclusion}

Muscle atrophy is a common finding and an important prognostic indicator among people with COPD; therefore, it should be assessed routinely in this population. Because the pathogenesis of muscle atrophy is complex and multifactorial, this area will be the subject of clinical investigation for many years to come.

\section{REFERENCES}

1. Argiles JM, Busquets S, Felipe A, Lopez-Soriano FJ. Muscle wasting in cancer and ageing: Cachexia versus sarcopenia. Adv Gerontol 2006;18:39-54.

2. Schols AM. Pulmonary cachexia. Int J Cardiol 2002;85:101-10.

3. Vermeeren MA, Creutzberg EC, Schols AM, et al; on behalf of the COSMIC Study Group. Prevalence of nutritional depletion in a large out-patient population of patients with COPD. Respir Med 2006;100:1349-55.

4. Vestbo J, Prescott E, Almdal T, et al. Body mass, fat-free body mass, and prognosis in patients with chronic obstructive pulmonary disease from a random population sample: Findings from the Copenhagen City Heart Study. Am J Respir Crit Care Med 2006;173:79-83.

5. Engelen MP, Deutz NE, Wouters EF, Schols AM. Enhanced levels of whole-body protein turnover in patients with chronic obstructive pulmonary disease. Am J Respir Crit Care Med 2000;162:1488-92.
6. Morrison WL, Gibson JN, Scrimgeour C, Rennie MJ. Muscle wasting in emphysema. Clin Sci (Lond) 1988;75:415-20.

7. Glickman MH, Ciechanover A. The ubiquitin-proteasome proteolytic pathway: Destruction for the sake of construction. Physiol Rev 2002;82:373-428.

8. Bodine SC, Latres E, Baumhueter S, et al. Identification of ubiquitin ligases required for skeletal muscle atrophy. Science 2001;294:1704-8.

9. Gomes MD, Lecker SH, Jagoe RT, Navon A, Goldberg AL. Atrogin-1, a muscle-specific F-box protein highly expressed during muscle atrophy. Proc Natl Acad Sci USA 2001;98:14440-5.

10. Sandri M, Sandri C, Gilbert A, et al. Foxo transcription factors induce the atrophy-related ubiquitin ligase atrogin-1 and cause skeletal muscle atrophy. Cell 2004;117:399-412.

11. Stitt TN, Drujan D, Clarke BA, et al. The IGF-1/PI3K/Akt pathway prevents expression of muscle atrophy-induced ubiquitin ligases by inhibiting FOXO transcription factors. Mol Cell 2004;14:395-403.

12. Buck M, Chojkier M. Muscle wasting and dedifferentiation induced by oxidative stress in a murine model of cachexia is prevented by inhibitors of nitric oxide synthesis and antioxidants. EMBO J 1996;15:1753-65.

13. Langen RC, Schols AM, Kelders MC, Van Der Velden JL, Wouters EF, Janssen-Heininger YM. Tumor necrosis factor-alpha inhibits myogenesis through redox-dependent and -independent pathways. Am J Physiol Cell Physiol 2002;283:C714-21.

14. Jakobsson P, Jorfeldt L, Brundin A. Skeletal muscle metabolites and fibre types in patients with advanced chronic obstructive pulmonary disease (COPD), with and without chronic respiratory failure. Eur Respir J 1990;3:192-6.

15. Rennie MJ, Wackerhage H, Spangenburg EE, Booth FW. Control of the size of the human muscle mass. Annu Rev Physiol 2004;66:799-828.

16. Bernard S, LeBlanc P, Whittom F, et al. Peripheral muscle weakness in patients with chronic obstructive pulmonary disease. Am J Respir Crit Care Med 1998;158:629-34.

17. Gosker HR, Lencer NH, Franssen FM, van der Vusse GJ, Wouters EF, Schols AM. Striking similarities in systemic factors contributing to decreased exercise capacity in patients with severe chronic heart failure or COPD. Chest 2003;123:1416-24.

18. Visser M, Goodpaster BH, Kritchevsky SB, et al. Muscle mass, muscle strength, and muscle fat infiltration as predictors of incident mobility limitations in well-functioning older persons. J Gerontol A Biol Sci Med Sci 2005;60:324-33.

19. Marquis K, Debigare R, Lacasse Y, et al. Midthigh muscle crosssectional area is a better predictor of mortality than body mass index in patients with chronic obstructive pulmonary disease. Am J Respir Crit Care Med 2002;166:809-13.

20. Steiner MC, Barton RL, Singh SJ, Morgan MD. Bedside methods versus dual energy $\mathrm{X}$-ray absorptiometry for body composition measurement in COPD. Eur Respir J 2002;19:626-31. 
21. Schols AM, Broekhuizen R, Weling-Scheepers CA, Wouters EF. Body composition and mortality in chronic obstructive pulmonary disease. Am J Clin Nutr 2005;82:53-9.

22. Engelen MP, Schols AM, Does JD, Wouters EF. Skeletal muscle weakness is associated with wasting of extremity fat-free mass but not with airflow obstruction in patients with chronic obstructive pulmonary disease. Am J Clin Nutr 2000;71:733-8.

23. Mathur S, MacIntyre DL, Forster BB, Levy RD, Road JD, Reid WD. Fat infiltration in the quadriceps and hamstrings in people with COPD and lung transplant recipients. Med Sci Sports Exerc 2005;37:S243. (Abst)

\section{THE VALUE OF PARTNERSHIPS: INITIATING A SUCCESSFUL COPD PROGRAM} Donna J Bleakney

An integrated, evidence-based, interdisciplinary COPD program was established in the Saskatoon Health Region (SHR), Saskatoon, Saskatchewan, using an innovative CDM model for care delivery (Table 8). The challenge in developing effective CDM programs in the health care system is to manage chronic conditions as effectively as acute situations. This approach to optimizing care is central to successfully dealing with most chronic medical conditions, including patient-centred outcomes, as well as program management, cost and coordination.

The SHR's COPD program is named the Live Well Optimizing COPD Program (Figure 8). The Chronic Illness Care model (1) was adopted as the model of choice. An interdisciplinary team, including many community and health region partners, was developed to optimize the care provided to patients with a primary diagnosis of COPD. The program combines exercise rehabilitation with enhanced patient self-management skills and follow-up by an interdisciplinary team of experts working closely with the patient and family, as well as with the patient's family physician. Ongoing evaluation of both patient and program outcomes is essential, and is facilitated by using the Live Well electronic data management program. The Live Well Optimizing COPD Program began as a pilot program in the SHR and was initially funded by the Saskatchewan Health Quality Council and the Lung Association of Saskatchewan. The pilot program was designed from published, evidencebased research and the experience of others, with the goals of improving patient care and decreasing hospitalizations and health care costs. The success of the pilot program led to implementation throughout the SHR.

Steps, goals and objectives

The following steps, goals and objectives were used to initiate the program.

\section{Steps:}

- Assess need

- Collect best evidence

- Obtain support from senior leadership

- Assess budget and funding needs

- Determine outcome measurements

- Develop meaningful partnerships

- Start with pilot programming

- Evaluate frequently and candidly
TABLE 8

Saskatoon Health Region's Live Well Program: Optimizing chronic disease management

\begin{tabular}{lcc}
\hline $\begin{array}{l}\text { Group exercise } \\
\text { and rehabilitation }\end{array}$ & $\begin{array}{c}\text { Disease-specific } \\
\text { management }\end{array}$ & $\begin{array}{c}\text { Patient self- } \\
\text { management skills }\end{array}$ \\
\hline $\begin{array}{l}\text { Community-based } \\
\text { supervised exercise }\end{array}$ & $\begin{array}{c}\text { Nurse-clinician working } \\
\text { with the patient, their }\end{array}$ & $\begin{array}{c}\text { Patient-led group } \\
\text { classes and support } \\
\text { family and the family } \\
\text { (Live Well with a }\end{array}$ \\
& $\begin{array}{l}\text { physician and/or } \\
\text { specialist }\end{array}$ & chronic disease program) \\
Group and social & Evidence-based optimal & Enhanced self- \\
support & care delivery & management skills and \\
& & decision-making \\
\hline
\end{tabular}

Saskatoon Health Region: Linkages and Partnerships

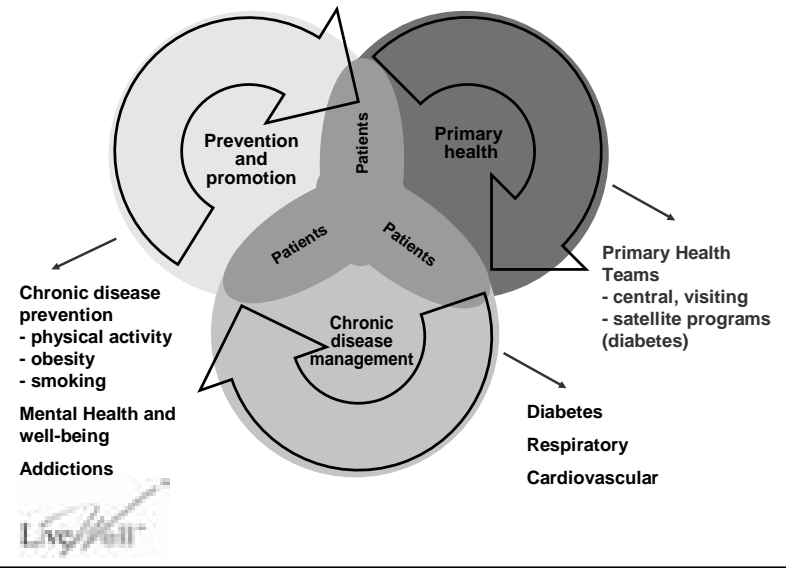

Figure 8) Saskatoon Health Region's Live Well Optimizing COPD Program

\section{Goals:}

- To optimize management and improve the quality of life for COPD patients and their families

- To promote a goal-directed interdisciplinary team approach for patient-centred self-management

\section{Objectives:}

- To integrate existing programs, develop new programs and build capacity

- To involve family physicians, home care staff and others in team-based care

- To develop services in urban and rural areas, including key underserviced areas

- To objectively evaluate patient care and outcomes

\section{Partnerships}

Partnerships allow for the sharing of costs, human resources and medical consultation, as well as for the donation of space and equipment when initiating programs. They allow for enhanced program promotion and stronger community relationships. Community partnerships include provincial lung associations, family physicians, industry, service clubs, provincial and civic governments, school boards, and academic and research communities.

The SHR's Live Well CDM Program has benefited from developing many partnerships within and outside the health 
region. Establishing and maintaining links among portfolios within the health region, including primary health and public health/prevention and promotion, and working in concert with CDM was imperative. The SHR has gained valuable knowledge from health regions in other provinces with existing but different programs, including the Calgary and Capital Health Regions in Alberta.

Expansion of the Living Well Program has occurred by partnering with local shopping malls and rural facilities to build capacity within the PR programs.

\section{Program design}

The program is designed with three pillars of care, each independently shown to deliver benefit and each essential to fully realize the success of the others. Each component (pillar) of the program strategically targets different aspects of care delivery.

The program design is applicable to most chronic medical conditions, but the greatest benefit would be realized for those diseases with the highest burden. For example, there is a large disconnect between current and optimal care in COPD, a very low level of disease awareness and a significant disease burden. In the SHR, COPD has the highest hospital readmission rate of all chronic diseases. Recent evidence (2) has demonstrated that targeting COPD patients with optimal care and outpatient, preventive interventions leads to less shortness of breath, increased exercise capacity, better quality of life and reduced health care use.

\section{Outcomes}

The pilot program in the SHR reduced COPD hospital readmission rates from $30 \%$ (2002) to $23 \%$ (2005) - a $23.3 \%$ reduction. The average length of hospital stay decreased from 11.0 to 8.6 days for patients with COPD within the SHR (3). The cost avoidance in 2004-2005 was estimated at $\$ 192,711$. The incremental program costs in the SHR were $\$ 112,832$, with an estimated net savings in one year of $\$ 79,879$, in addition to the patient-centred benefits. For every dollar invested in the program, there was an avoidance of $\$ 1.70$ in direct health care costs for COPD alone. Moreover, days spent in the intensive care unit for COPD decreased by $44 \%$, with an additional estimated cost savings of \$261,333 (2004-2005).

\section{Conclusion}

The program is based on evidence-based care (ie, what has been proven to work) rather than what we think may help. Successful COPD program outcomes based on a CDM approach and with strong partnerships has allowed the SHR to not only maintain the program but expand to include satellite programs within the region and throughout the province. This model will be used as the template to develop provincial COPD programming integrated with a provincial rehabilitation program.

ACKNOWLEDGEMENT: The assistance of Ms Jan Haffner and Dr Darcy Marciniuk in preparing this article was greatly appreciated.

\section{REFERENCES}

1. Wagner EH. Chronic disease management: What will it take to improve care for chronic illness? Eff Clin Pract 1998;1:2-4.

2. O'Donnell DE, Aaron S, Bourbeau J, et al. State of the Art Compendium: Canadian Thoracic Society recommendations for the management of chronic obstructive pulmonary disease. Can Respir J 2004;11(Suppl B):7B-59B.

3. 2006 Strategic Health and Information Planning Service, Saskatoon Health Region. Saskatoon, 2006.

\section{BURDEN-PROVIDER FOCUS: INTERDISCIPLINARY CARE}

\author{
Sandra Delon, Jennifer McNish, \\ Louise Morrin, Janet Philpott, \\ Tracy Smith, Sarah Wright
}

The Calgary Health Region's CDM program is based on the chronic care model developed by the MacColl Institute for Health Care Innovation (1). Strategies used by the Calgary Health Region to implement the model include nurse case management, algorithm-driven care, specialist expertise in primary care, an electronic chronic disease information management system and the Living Well with a Chronic Condition program for people with chronic diseases. The following describes the Living Well with a Chronic Condition program, emphasizing the role of the interdisciplinary team.

\section{The Living Well with a Chronic Condition Program}

Living Well with a Chronic Condition is a community-based program that provides exercise, disease-specific education and self-management workshops for people with chronic conditions. The program combines all the elements of optimal chronic care, such as community partnerships, follow-up and interdisciplinary care. The program is delivered by a team of kinesiologists, physiotherapists, respiratory therapists, occupational therapists, dietitians and social workers.

Delivering all three pillars of the program close to the client's community reduces barriers to participation. It is made possible through partnerships with community centres as well as local sports and recreation facilities. Living Well with a Chronic Condition provides the infrastructure, such as rented space and clerical support, for specialty clinics to deliver disease-specific education in the community. The exercise component operates at 15 sites throughout the region, including four rural sites. Individuals with various chronic conditions are triaged, according to their functional level, to one of three levels of exercise intensity - 'Easy Going', 'Get Going' or 'Keep Going'. The self-management arm of the program is called 'Row Your Own Boat'. It comprises workshop sessions, led by lay leaders with chronic conditions, with the goals of building confidence to cope with chronic illness and teaching skills to self-manage day to day challenges. Programs are delivered in a culturally sensitive manner, to diverse populations. Importantly, this is a grassroots, relatively low cost program that can be customized to fit local CDM strategies and frameworks.

The following sections describe the roles played by the interdisciplinary team members in the program.

Kinesiologists: Kinesiologists provide expertise in exercise physiology. This expertise is applied through health appraisal, and exercise testing, programming and prescription. Kinesiologists assist with exercise counselling and goal setting, and provide group education classes that focus on exercise in chronic conditions for each of the three levels of the program. At most sites, kinesiologists are supported by community fitness leaders employed at the community site. The fitness leaders lead group exercise classes, supervise maintenance classes for program graduates and assist with the exercise prescription.

Physiotherapists: Physiotherapists are involved in direct client care and program development. This involves the following: 
- assessment (respiratory, balance, gait, mobility aids and footwear)

- treatment (group and individual exercise programs)

- education (self-management, disease specific and nondisease specific)

The physiotherapists' role in program development is focused on the 'Easy Going' and 'Get Going' groups. They select and standardize the outcome measures, assessment procedures and documentation, and they organize the exercise classes. The physiotherapists' role has developed from being diagnosis based to being function based. Given the large number of participants with musculoskeletal and neurological conditions, there is a high need for physiotherapists' skills in the 'Get Going' and 'Easy Going' programs.

Respiratory therapists: Respiratory therapists support the exercise and education programs for clients with chronic respiratory illnesses. Their roles include the following:

- initial and recall assessments

- oxygen prescriptions

- medication review and proper inhaler technique

- smoking cessation counselling

- support for maintenance groups

- disease-specific education

- 'Get Going' program organization and development

- respiratory consultation for the 'Keep Going' and 'Easy Going' programs

Occupational therapists: Occupational therapists assess function in many aspects of living, such as self-care, productivity and leisure. They focus on clients with comorbidities that limit their functional mobility and are therefore largely involved in the development and delivery of the 'Easy Going' program, for individuals who cannot participate in the more strenuous exercises of the 'Get Going' and 'Keep Going' programs. They participate in group education, including topics such as energy conservation, relaxation and stress management, and they conduct cognitive assessments if there are concerns regarding a client's mental state, to ensure that the safety of the group will not be compromised. The occupational therapists authorize mobility aids through the Alberta Aids to Daily Living program because some clients have comorbidities that affect their functioning.

\section{Comment}

The Living Well with a Chronic Condition team members work together to help remove the barriers to exercise and to help promote self-management through group education as well as individual consultation. This community-based, interdisciplinary model has had to tackle issues such as role definition, developing mutual trust among the team and developing a program where no blueprint existed. Ongoing challenges relate to acquiring adequate space and equipment in community facilities on desirable days and times, standardizing program operations across multiple sites and adapting group exercise programs for clients with a wide range of abilities. Disseminating appropriate health information for screening, accessing physicians and programming in an efficient manner remain ongoing operational concerns. Upgrading a disease management information system to meet the needs of an evolving program, as well as accessing the administrative infrastructure, continue to pose challenges.

\section{Conclusion}

The Living Well with a Chronic Condition program is a collaborative effort among a large, interdisciplinary team who embodies the skills to provide a comprehensive program of exercise, education and self-management, as well as a nourishing environment for clients with chronic diseases and their professional staff.

\section{REFERENCE}

1. Improving Chronic Illness Care. <www.improvingchroniccare.org> (Version current at April 24, 2007).

\section{BEHAVIOUR CHANGE GETTING TO WELLNESS Kate Lorig}

Chronic disease requires changes in health care practice because the goal of managing relates more closely to function and comfort than to cure. The site of care shifts from the institution to the community, and the role of the health care provider changes from principle caregiver to teacher and partner. Inevitably, these changes also influence the role of the patient. The patient becomes more responsible for managing the condition, maintaining life roles, dealing with the emotional consequences of a chronic disease and being the carrier of vital information. Health care providers used to a certain style of practice are challenged to recognize a different approach to ensure that they have the necessary knowledge and skills, as well as the time. All of this is easily surmountable if they believe that chronic disease selfmanagement will work.

\section{Definition of self-management}

Self-management has been defined as the task that individuals must undertake to live with one or more chronic conditions. These tasks include having the confidence to deal with the medical management, role management and emotional management of their conditions (1). Self-management support is defined as the systematic provision of education and supportive interventions by the health care system to increase patient skills and confidence in managing their health problems, including the regular assessment of progress and problems, goal setting and problem solving (2).

Whereas the goal of more traditional case management is to contain costs through efficient health care, self-management support focuses more on improving quality of life by providing patients with the skills that they need to manage their lives in the face of chronic illness. One example of self-management support is the Stanford Chronic Disease SelfManagement Program (CDSMP). This program is built on structured patient and professional needs assessments and strategies to enhance self-efficacy, such as goal setting, modelling, interpreting symptoms and social persuasion. The selfmanagement programs occur in small groups that are peer-led by two individuals with chronic conditions. These group leaders receive standardized training and are given a highly structured teaching protocol with standardized participant materials. 


\section{TABLE 9}

Self-management support tips

Base teaching on patient's concerns

Screen frequently for depression

Have patients set specific goals

Expand patient's beliefs

Tell patients when to expect effects

Do not ignore insignificant medical findings

Arrange for patients to meet other patients

Each small group comprises 10 to 15 people with various chronic diseases. The group meets for $2 \mathrm{~h}$ to $3 \mathrm{~h}$ a week for six weeks and tackles issues such as symptom management (pain, depression, shortness of breath and fatigue), exercise, nutrition, problem solving, communications, appropriate use of medications, working with health care professionals and advanced directives.

A published report of the CDSMP (3) noted that the average patient was 62 years old, men comprised $27 \%$ of the group and each individual had 2.2 chronic diseases. Among the participants, 21\% had lung disease, 24\% had heart disease, 26\% had diabetes and $42 \%$ had arthritis. After six months, there were improvements in self-rated health outcomes, disability, social role and activities, energy and distress with their health state. Participants averaged just under one day less in hospital when compared with the previous six months $(\mathrm{P}=0.02)$, at an estimated intervention cost of approximately US $\$ 200$ per subject (3).

In a study by Lorig et al (4) of Spanish-speaking subjects (Tomando Control de Su Salud), 63\% of subjects were Mexican, 21\% were from Central America, 7\% were from the United States and 9\% were from other countries. It was noted that at four months, there were important improvements in self-rated health, health distress, fatigue, disability and role activity (4). In a second trial (5) of this program in patients with type 2 diabetes, there was an increase in self-monitoring of blood glucose, an increase in the daily intake of fruits and vegetables, improved communication with physicians and increased exercise.

In Stanford's Internet-based self-management program entitled 'Self-Management @ Stanford: Healthier Living With Ongoing Health Problems', individuals with heart disease, lung disease or diabetes engage in a highly interactive self-management program. They are asked to log on two to three times a week over a six-week period. To date, 958 individuals have been randomly assigned to the program, with a mean age of 55 years (range 20 to 87 years) and $70 \%$ of whom are female. After one year, follow-up of 782 participants showed important improvements in communicating with providers, exercising, shortness of breath, and symptoms of health distress and pain (6).

Chronic disease self-management is now used in many Canadian jurisdictions, as well as in Europe and Asia. In the United States, it has been adopted by leading health plans. Successful programs emphasize problem solving, goal setting, improved self-efficacy, self-tailoring and patients helping patients. Challenges to implementation include buy-in from health care professionals, secure funding, logistical management, program coordination and organizational leadership support. Key tips are summarized in Table 9. Teaching CDSMP using these strategies has been an enormously rewarding undertaking.

\section{REFERENCES}

1. Adams K, Greiner AC, Corrigan JM, eds. Report of a summit. The 1st Annual Crossing the Quality Chasm Summit - A Focus on Communities. Washington: National Academies Press, 2004.

2. Von Korff M, Gruman J, Schaefer J, Curry SJ, Wagner EH. Collaborative management of chronic illness. Ann Intern Med 1997;127:1097-102.

3. Lorig KR, Sobel DS, Stewart AL, et al. Evidence suggesting that a chronic disease self-management program can improve health status while reducing hospitalization: A randomized trial. Med Care 1999;37:5-14.

4. Lorig KR, Ritter PL, González VM. Hispanic chronic disease selfmanagement: A randomized community-based outcome trial. Nurs Res 2003;52:361-9.

5. Lorig KR, Ritter PL, Jacquez A. Outcomes of border health Spanish/English chronic disease self-management programs. Diabetes Educ 2005;31:401-9.

6. Lorig KR, Ritter PL, Laurent DD, Plant K. Internet-based chronic disease self-management: A randomized trial. Med Care 2006;44:964-71. (Erratum in 2007;45:276).

\section{BUILDING A SYSTEM OF CARE FOR PEOPLE WITH CHRONIC ILLNESS: THE CHRONIC CARE MODEL - HINDSIGHT HEALTH CARE STRATEGIES \\ Michael Fosbery Hindmarsh}

As more people with chronic illness are forced through the current acute care system, patient outcomes continue to decline. The system encourages patients to present only when symptomatic. They are rushed through short appointments, ending in a series of prescriptions and treatment instructions they likely do not understand. Follow-up does not occur and patients are left managing alone, usually unsuccessfully. Over time, they spiral down into worsening health.

Asking providers to work harder or admonishing patients to be more compliant will not work. What is needed is fundamental change to the system that proactively meets the needs of all chronically ill patients. That is the premise behind the chronic care model (CCM) (Figure 9) (1-3).

\section{Productive interactions between patients and providers}

To have a productive interaction, there needs to be an informed, activated patient on one side and a prepared, proactive team on the other. The informed, activated patient is one who understands their disease process and is empowered to self-manage their care. A prepared, proactive practice team is one that has the right information, decision support, equipment and personnel at the time of the visit.

The interaction is one in which all clinical and behavioural assessments are available before the visit. Clinical care is tailored by a stepped protocol. Collaborative goal setting and problem solving result in a shared care plan that both the patient and the provider understand. There is active, sustained follow-up to ensure that the patient is managing well.

To get to this productive interaction, the health care system must redesign itself according to the six components in the upper part of the CCM. The key changes necessary to redesign care are listed, by component, below. 


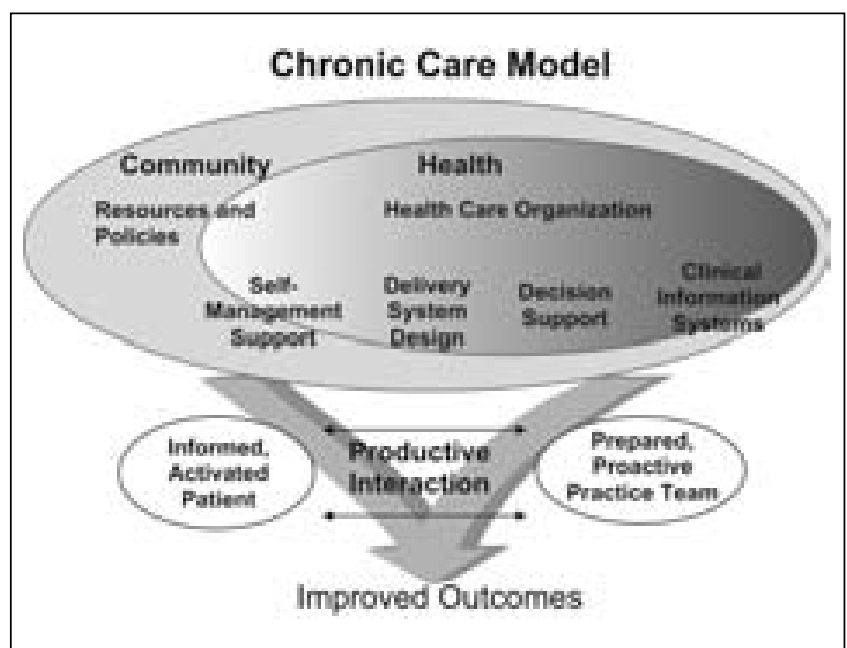

Figure 9) Chronic care model. Reproduced with permission from reference 2

\section{Health care organization}

- Visibly support improvement at all levels, starting with senior leaders.

- Promote effective improvement strategies aimed at comprehensive system change.

- Encourage open and systematic handling of problems.

- Provide incentives based on quality of care.

- Develop agreements for care coordination.

\section{Community resources}

- Encourage patients to participate in effective programs.

- Form partnerships with community organizations to support or develop programs.

- Advocate for policies to improve care.

\section{Self-management support}

- Emphasize the patient's central role as the manager of their illness.

- Use self-management support strategies that include assessment, collaborative goal setting, action planning, problem solving and follow-up.

- Organize resources to provide support.

\section{Delivery system design}

- Define roles and distribute tasks among team members.

- Use planned interactions to support evidence-based care.

- Provide clinical case management services.

- Ensure regular follow-up.

- Give care that patients understand and that fits their culture.

\section{Decision support}

- Embed evidence-based guidelines into daily clinical practice.

- Integrate specialist expertise and primary care.

- Use proven provider education methods.

- Share guidelines and information with patients.

Clinical information systems

- Provide reminders for providers and patients.

- Identify relevant patient subpopulations for proactive care.

- Facilitate individual patient care planning.

- Share information with providers and patients.

- Monitor the performance of the team and the system.

\section{Evidence supporting the $\mathrm{CCM}$}

There are numerous studies of American systems in which the CCM has been implemented (4), in particular the research of the RAND Corporation, funded by the Robert Wood Johnson Foundation, to assess the effectiveness of implementing the CCM (5).

In this study (5), the following research questions were asked: can health care organizations successfully implement all components of the CCM?, and does implementing the model result in improved process and clinical outcomes?

The study was a pre-post controlled design with 34 practice teams from various organizations in the intervention arm and 24 control teams from the same organizations. Interventions were selected from four national learning collaboratives conducted by the Institute for Healthcare Improvement and the MacColl Institute.

The study examined populations with diabetes, asthma and congestive heart failure. For patients with diabetes, while there were not significant differences in hemoglobin $\mathrm{A} 1 \mathrm{C}$, there were improved A1Cs in both the intervention and the control arms, due in large part to contamination at the clinical site. For patients with congestive heart failure, there were significant improvements in congestive heart failure counselling, patient education and emergency room readmissions. For patients with asthma, there were significant improvements in patients on controller medications, as well as significant improvements in quality of life. Most organizations were able to redesign care using all components of the CCM.

\section{The CCM in other countries}

The World Health Organization adapted the CCM to fit the governmental and policy structures of most developing countries (6). The major focus is to create positive policy environments that promote consistent financing and develop the needed human resources to deliver chronic care.

The National Health System (NHS) in the United Kingdom draws on the CCM and the Kaiser Permanente pyramid. The key components of the NHS model link the health care system with the social care system. They place the patients and their caregivers at the centre of that relationship. They are targeting long-term conditions and risk stratifying chronically ill patients for targeted interventions, with an emphasis on frequent users, and the use of multidisciplinary teams in primary care. 
New Zealand's Medical Outcomes Intervention is using the CCM in an attempt to divert hospital use as the primary care medical home.

Australia's Chronic Disease Model for Prevention and Control is a public health model that attempts to target and stratify chronically ill patients and match them to the appropriate services, similar to that of the NHS in the United Kingdom.

\section{The CCM in Canada}

British Columbia has created an Expanded CCM, which emphasizes the community as a critical component to supporting care. Alberta's Capital and Calgary Health Regions are implementing registry-based information technologies and self-management support programs. Saskatchewan is running learning collaboratives for all primary care. Ontario has also adapted the model to incorporate the need for healthy public policy that creates supportive physical and social environments. The Atlantic provinces' project 'Building Better Tomorrows' is teaching primary care providers about chronic illness management and practice change.

In summary, the CCM is a system redesign strategy that is being widely adopted and adapted in health care settings around the globe. Successful implementation of the model stems from the understanding of health care leaders that realize they cannot tinker around the edges of current broken acute care systems, but instead must build a new system.

ACKNOWLEDGEMENT: The chronic care model presented in this manuscript is a product of years of research and dissemination by the staff at the MacColl Institute for Healthcare Innovation at Group Health Cooperative in Seattle, Washington, USA. The Institute is led by Ed Wagner MD MPH, whose leadership and vision enabled all of us at MacColl to excel in the field of improving care for chronically ill patients.

\section{REFERENCES}

1. Wagner EH, Austin BT, Davis C, Hindmarsh M, Schaefer J, Bonomi A. Improving chronic illness care: Translating evidence into action. Health Aff (Millwood) 2001;20:64-78.

2. Wagner EH. Chronic disease management: What will it take to improve care for chronic illness? Eff Clin Pract 1998;1:2-4.

3. Bodenheimer T, Wagner EH, Grumbach K. Improving primary care for patients with chronic illness: The chronic care model, Part 2. JAMA 2002;288:1909-14.

4. The Chronic Care Model - Footnotes. <http://www.improvingchronic care.org/index.php?p=Footnotes\&s=101> (Version current at April 11, 2007).

5. Improving Chronic Illness Care Evaluation: A Rand Health Program. $<$ www.rand.org/health/ICICE> (Version current at April 11, 2007).

6. Singh D, Ham C. Improving care for people with long-term conditions. A review of UK and international frameworks. Health Services Management Centre/NHS Institute for Innovation and Improvement, 2006.

\section{PATIENT SELF-MANAGEMENT: A KEY TO SUCCESS FOR COPD MANAGEMENT}

\author{
Diane Nault
}

One of the most important keys to success in the management of COPD is patient self-management. The literature on the effectiveness of self-management interventions for COPD patients is controversial and highlights the need for additional well-designed trials in the field (1). Bourbeau et al (2) conducted a multicentre randomized controlled trial, and noted marked improvements in health care services use following participation in the self-management program 'Living Well with COPD'. After one-year follow-up, the authors reported a reduction of $42 \%$ in hospitalizations and of 36\% in emergency room department visits among those who participated in the self-management program compared with those who received usual care. A systematic review by Adams et al (3) highlighted the fact that outcomes in COPD patients seem to improve when patient education programs combine self-management education with other components of the CCM (4). The self-management program 'Living Well with COPD' (5) integrates three of the four CCM components. Education alone, although beneficial, is not sufficient to change behaviour. A self-management program should include reference guides for health professionals, written modules for patients, patient education based on an assessment of their learning needs (6), enhancement of self-efficacy (7) and integration of self-management skills in day-to-day life leading to specific behaviour changes (8).

Educational approaches for individual or group sessions include interactive lecturing, case scenarios, practice, constructive feedback and reinforcement. They are helped by group discussions, peer observation, learning contracts and written material adapted to the level of literacy of the subjects. Such programs target the development of healthy behaviours to encourage patients to become self-managers of their COPD. Patients will learn how to manage dyspnea, save energy, live in a smoke-free environment and take their medications, as well as to manage exacerbations, stress and anxiety. Additional educational goals include maintaining an active lifestyle, eating and sleeping well, maintaining a satisfying sex life and being involved in leisure activities.

A complementary qualitative study (9), linked to the Bourbeau program, revealed that the most helpful self-management skills still used by COPD patients after one year follow-up were the principles of energy conservation, the pursed-lip breathing technique, the use of an action plan and the practice of an exercise program.

In conclusion, effective COPD management requires patient self-management, which is only possible when a strong partnership exists between patients and their medical team. Evidence-based patient education interventions are used by health care professionals and are now available to support a case manager. Further research is needed to evaluate the effects of self-management programs on behaviour changes in COPD, as well as on patients' use of action plans.

ACKNOWLEDGEMENTS: The author thanks Dr Jean Bourbeau, Ms Maria Sedeno, Mr Henri Tremblay, the Montreal Chest Institute's multidisciplinary team, respirologists, health professionals and patients from many regions in Canada, Boehringer Ingelheim and Pfizer, Fonds de la recherche en santé du Québec Respiratory Network, the Lung Associations, and the Québec Asthma and COPD Network.

\section{REFERENCES}

1. Taylor SJ, Candy B, Bryar RM, et al. Effectiveness of innovations in nurse led chronic disease management for patients with chronic obstructive pulmonary disease: Systematic review of evidence. BM] 2005;331:485

2. Bourbeau J, Julien M, Maltais F, et al; Chronic Obstructive Pulmonary Disease axis of the Respiratory Network Fonds de la Recherche en Sante du Quebec. Reduction of hospital utilization in patients with chronic obstructive pulmonary disease: A diseasespecific self-management intervention. Arch Intern Med 2003;163:585-91

3. Adams SG, Smith PK, Cornell JE, Anzueto A, Pugh JA. Systematic review of disease management in chronic obstructive pulmonary disease. Chest 2005;128:257S. (Abst) 
4. Wagner EH, Glasgow RE, Davis C, et al. Quality improvement in chronic illness care: A collaborative approach. Jt Comm J Qual Improv 2001;27:63-80.

5. Living Well with COPD. <http://www.livingwellwithcopd.com/ english/home/default.asp?s=1> (Version current at April 11, 2007).

6. Green LW, Kreuter MW. Health promotion planning: An educational and environmental approach. 3rd edn. London: Mayfield Publishing Company, 1999.

7. Bandura A. The assessment and predictive generality of self-percepts of efficacy. J Behav Ther Exp Psychiatry 1982;13:195-9.

8. Lorig KR, Holman H. Self-management education: History, definition, outcomes, and mechanisms. Ann Behav Med 2003;26:1-7.

9. Nault D, Pepin J, Dagenais J, et al. Qualitative evaluation of a selfmanagement program "Living Well with COPD" offered to patients and their caregivers. Am J Resp Crit Care Med 2000;161:A56. (Abst)

\section{NEXT STEPS TO ACHIEVING WELLNESS}

\section{Roger S Goldstein}

The stimulating program that Dr Gordon Ford and his colleagues planned and executed so well enabled us to consider some of the many facets of COPD. In closing, I have been asked to comment on some of the next steps to achieving wellness. These are some of the many issues that we anticipate addressing at our next Canadian COPD Alliance Conference in 2008.

\section{Prevalence of COPD}

Recent information from the Public Health Agency of Canada shows the prevalence of physician-diagnosed COPD among adults aged 35 years and older over the past few years (Figure 10) (1). The percentage of men with COPD (2001 to 2005) is 3.8\% to $4.1 \%$, and the percentage of women with COPD is higher at $4.8 \%$ to $5.2 \%$, giving a combined prevalence in 2005 of $4.3 \%$. Because this information was extrapolated from a mail survey, it is likely that other, more direct sampling methods, such as those associated with the BOLD study (2), will yield higher prevalence rates than previously recognized. Therefore, one of the next steps is to clarify the prevalence of COPD among men and women to enable us to plan our provincial and federal strategies for COPD management. It is clear that when COPD mortality is displayed by province or territory, the rate is dramatically higher in the Northwest Territories and Nunavut (Figure 11), where it exceeds 109 per 100,000 population, than in the rest of Canada, where it is 30 per 100,000 population. Given this information, another important next step is to protect the health of our northern population by investing in a meaningful strategy to diagnose and manage COPD more effectively in these regions.

\section{COPD in women}

Since 2000, female mortality attributable to COPD has risen at double the rate attributable to breast cancer (9\% compared with $4 \%)$, while female mortality due to stroke has decreased by $2 \%$. Despite the rising prevalence of COPD among women, the COPD population continues to be predominantly male. It is possible that women may be more susceptible to COPD than men and that the clinical expression of COPD may differ between the sexes with a greater degree of hyperinflation in women (3). Therefore, one of the next steps is for Canadians to recognize that COPD is a crucial women's health issue, with more than 425,000 Canadian women being diagnosed with COPD and more than 4300 dying from it every year. The extent to which cigarette smoke has a greater impact on women's lung health, due to women's smaller lung capacity, or women's experience of dyspnea remains to be determined. Of note, older women frequently report breathlessness as the main reason for physical activity restriction (4).

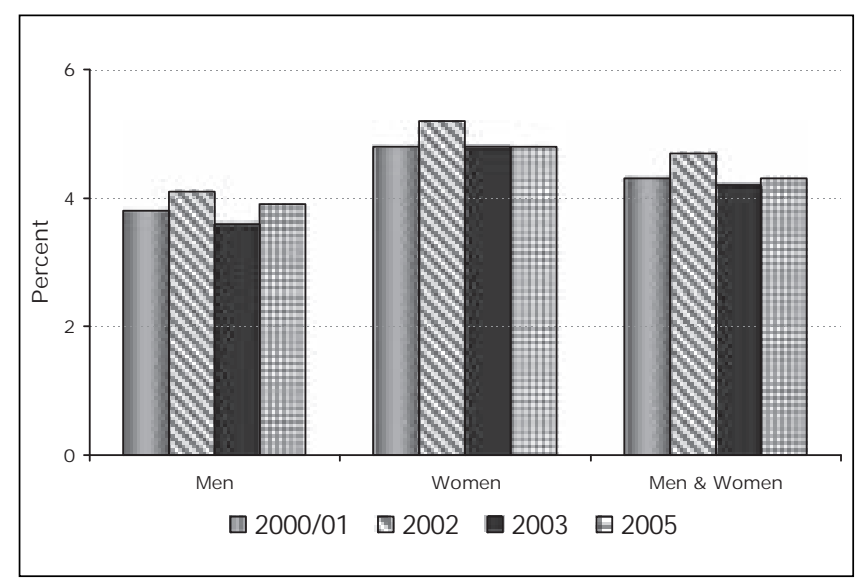

Figure 10) Prevalence of physician-diagnosed chronic obstrutive pulmonary disease among adults aged 35 years and older. Reproduced with permission from reference 1

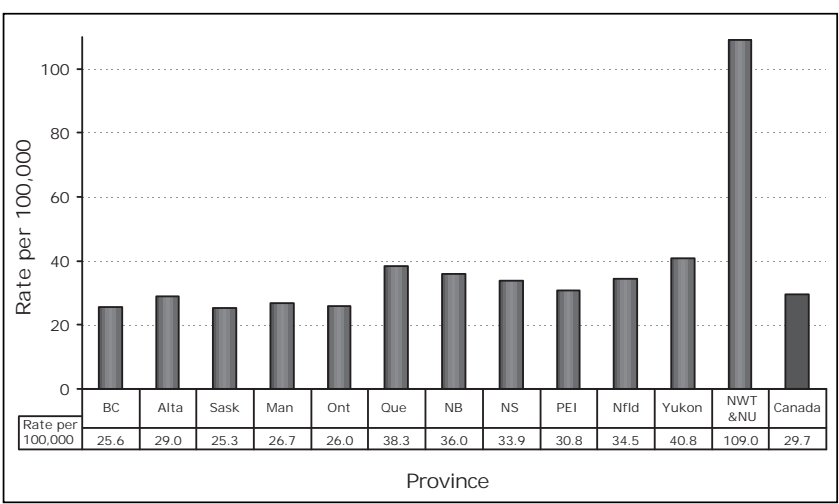

Figure 11) Chronic obstructive pulmonary disease mortality rates, 1998 to 2000. Reproduced with permission from reference 1. Alta Alberta; BC British Columbia; Man Manitoba; NB New Brunswick; Nfld Newfoundland; NS Nova Scotia; NWT Eु NU Northwest Territories and Nunavut; Ont Ontario; PEI Prince Edward Island; Que Quebec; Sask Saskatchewan

\section{Wellness and spirometry}

Remarkably, the recent Canadian Lung Association national report entitled 'Women in COPD' (4) noted that although the majority of Canadians were aware of the importance of electrocardiograms and mammography, and more than $25 \%$ of Canadians had heard of bone densitometry for osteoporosis, just $10 \%$ of Canadians had heard of spirometry (Figure 12) (4). We need to define what our investment in spirometry should be. The spirometer is clearly an excellent aid for case finding, tracking the progress of airflow limitation and quantifying a bronchodilator response. Only a minority of family physicians identify themselves as being very comfortable interpreting spirometry. Therefore, further investment in the training of health care providers to accurately carry out spirometry should be preceded by a better understanding of its role. For example, does earlier and more precise case finding result in lower downstream effects of morbidity, mortality or cost? Does it improve quality of life for those diagnosed at an earlier time in the course of their condition? Answering these important questions may require family physician test sites, at which the downstream impact of readily available spirometry may be better understood. 


\section{Spirometry? Never heard of it!}

- The majority of Canadians are aware of electrocardiograms (89\%) and mammography (68\%). More than one-quarter of Canadians have heard of a densitometry test ( $28 \%$ ).

- In contrast, just $10 \%$ of Canadians have heard of spirometry.

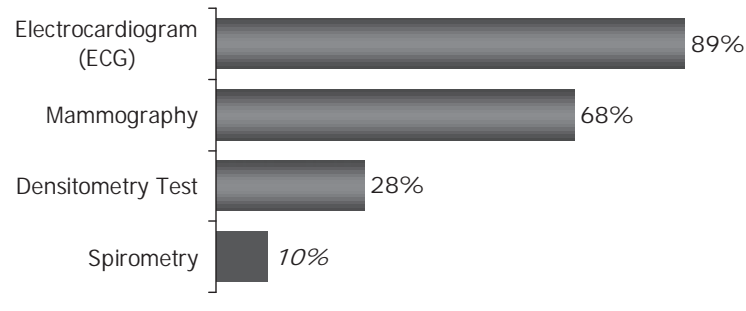

Q2: “Have you ever heard of...?” [n=1500]

Figure 12) Percentage of Canadians who have heard of electrocardiograms, mammography, densitometry tests and spirometry. Reproduced with permission from reference 4

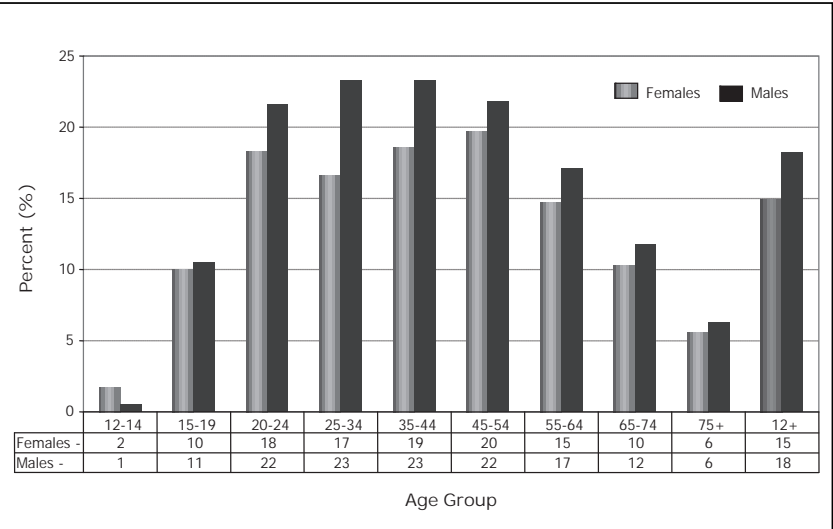

Figure 13) Current daily smokers by age group and sex in Canada, 2005. Reproduced with permission from reference 1

\section{Smoking}

Smoking rates in Canada continue to fall, with approximately $18 \%$ of Canadians aged 15 years and older smoking an average of 15 cigarettes per day (Figure 13). Smoking remains the number one preventable cause of death, killing more than 47,000 Canadians each year and accounting for $95 \%$ of cases of COPD. Another 8000 deaths per year are attributable to second-hand smoke, with a current exposure of $10 \%$ of children younger than 12 years, representing 380,000 Canadians. Smoking at work was considered restricted by more than $65 \%$ of respondents (1). In the province of Ontario, the burden of smoking represents $\$ 1.7$ billion per year in health costs, 500,000 days spent in hospital and $\$ 2.6$ billion per year in lost productivity (1). Therefore, we need to ask ourselves whether our current investment in smoking cessation is reasonable.

\section{CDM}

CDM emphasizes the important differences between acute and chronic conditions. As shown in Table 10, chronic illness results from multiple causes and is not generally cured. With chronic illnesses, health care professionals and patients both have complementary knowledge and experiences, in contrast with acute illness, in which the health care professionals' knowledge vastly exceeds that of the patients.
TABLE 10

Differences between acute and chronic conditions

\begin{tabular}{|c|c|c|}
\hline & Acute disease & Chronic illness \\
\hline Onset & Abrupt & Gradual and often insidious \\
\hline Duration & Limited & Lengthy and indefinite \\
\hline Cause & Usually single & Multiple and changes over time \\
\hline $\begin{array}{l}\text { Diagnosis and } \\
\text { prognosis }\end{array}$ & Usually accurate & Often uncertain \\
\hline Intervention & Usually effective & $\begin{array}{l}\text { Often indecisive; adverse } \\
\text { effects common }\end{array}$ \\
\hline Outcome & Cure possible & No cure \\
\hline Uncertainty & Minimal & Pervasive \\
\hline Knowledge & $\begin{array}{l}\text { HCPs knowledgeable } \\
\text { and patients } \\
\text { inexperienced }\end{array}$ & $\begin{array}{l}\text { HCPs and patients have } \\
\text { complementary knowledge } \\
\text { and experiences }\end{array}$ \\
\hline
\end{tabular}

HCP Health care professional

\begin{tabular}{|c|c|c|c|c|c|c|c|}
\hline \multirow{3}{*}{$\frac{\text { Study }}{\text { Behnke 2000a }}$} & \multirow{2}{*}{\multicolumn{2}{|c|}{$\begin{array}{l}\text { Rehab } \\
\text { Mean (SD) }\end{array}$}} & \multicolumn{2}{|c|}{ Usual Care } & $\begin{array}{l}\text { Weighted Mean } \\
\text { Difference(Random) }\end{array}$ & \multirow{2}{*}{$\begin{array}{l}\text { Weight } \\
(\%)\end{array}$} & \multirow{2}{*}{$\begin{array}{c}\text { Weighted Mean } \\
\text { Difference (Random) } \\
95 \% \mathrm{Cl} \\
\end{array}$} \\
\hline & & & $\mathrm{N}$ & Mean (SD) & $95 \% \mathrm{Cl}$ & & \\
\hline & 15 & $2.42(1.24)$ & 15 & $0.16(1.32)$ & -6 & 4.6 & $2.26[1.34,3.18]$ \\
\hline Cambach 1997 & 13 & $1.20(1.20)$ & 8 & $0.00(0.80)$ & 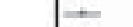 & 5.5 & $1.20[0.36,2.04]$ \\
\hline Goldstein 1994 & 40 & $0.68(1.14)$ & 39 & $0.02(1.30)$ & a. & 11.8 & $0.66[0.12,1.20]$ \\
\hline Gosselink 2000 & 34 & $0.80(1.28)$ & 28 & $-0.02(1.32)$ & -. & 8.6 & $0.82[0.17,1.47]$ \\
\hline Griffiths 2000 & 93 & $1.00(1.28)$ & 91 & $-0.18(1.00)$ & * & 24.3 & $1.18[0.85,1.51]$ \\
\hline Guell 1995 & 29 & $1.20(1.40)$ & 27 & $-0.10(1.10)$ & + & 8.5 & $1.30[0.64,1.96]$ \\
\hline Guell 1998 & 18 & $0.80(1.20)$ & 17 & $-0.20(1.20)$ & - & 6.0 & $1.00[0.20,1.80]$ \\
\hline Hernandez 2000 & 20 & $1.08(1.14)$ & 17 & $0.30(1.20)$ & - & 6.6 & $0.78[0.02,1.80]$ \\
\hline Simpson 1992 & 12 & $1.20(1.14)$ & 10 & $0.00(0.84)$ & $\rightarrow$ & 5.6 & $1.20[0.37,2.03]$ \\
\hline Singh 2003 & 20 & $0.96(0.88)$ & 20 & $0.08(0.84)$ & $\rightarrow$ & 12.1 & $0.88[0.35,1.41]$ \\
\hline Wijkstra 1994 & 28 & $0.86(1.02)$ & 15 & $-0.04(1.32)$ & $\rightarrow$ & 6.4 & $0.90[0.85,1.26]$ \\
\hline Total $(95 \% \mathrm{Cl})$ & 323 & & 287 & & • & 100.0 & $1.06[0.85,1.26]$ \\
\hline \multicolumn{8}{|c|}{ Test for heterogeneity chi-square $=11.60 \mathrm{df}=10 \mathrm{p}=0.31 \mathrm{I}^{2}=13.8 \%$} \\
\hline \multicolumn{8}{|c|}{ Test for overall effect $z=10.13 p<0.00001$} \\
\hline & & & & $\begin{array}{rr}-4.0 & -2.0 \\
\text { Favours cont }\end{array}$ & $\begin{array}{r}2.0 \\
\text { Favour }\end{array}$ & $\begin{array}{l}4.0 \\
\text { atment }\end{array}$ & \\
\hline
\end{tabular}

Figure 14) Meta-analysis of randomized controlled trials of pulmonary rehabilitation. A comparison of rehabilitation versus usual care for the dyspnea domain of the Chronic Respiratory Questionnaire is shown. Reproduced with permission from reference 5

Implementing CDM requires a change in health care practice, with an understanding that the goal is function rather than cure, the site of care changes from the clinic or hospital to the community, and the health care professional becomes a teacher and partner. The patient must learn to manage their disease, maintain their life role and deal with the emotional consequences of chronic illness.

One of the next steps to achieving wellness is to promote integration across care settings, promote the use of valid outcome measures (beyond death or hospitalization) and take advantage of the commonalities among chronic conditions.

\section{Rehabilitation - Exercise}

Supervised exercise training for more than four weeks is clearly effective in improving dyspnea, fatigue, emotional function and mastery (Figure 14) (5). Outstanding questions relate to whether exercise training should be institutionally based, home based or community based, and if the latter, how best to partner it with a community facility. We will only achieve wellness when rehabilitation moves from an acute treatment of four to six weeks' duration to a longer term strategy for maintaining 
health. Whereas the early definition of rehabilitation focused on supervised exercise, education and psychological support, achieving wellness for those with COPD requires longer term care and a broader spectrum of support, including immunization, optimum pharmacological management, attention to exacerbations, assessment for oxygen therapy, self-management, nutrition and a realistic exercise routine.

ACKNOWLEDGEMENTS: The author thanks the organizing scientific and program committees, the sponsors, the partners and the participants for a stimulating consideration of modern COPD management.

\section{REFERENCES}

1. Centre for Chronic Disease Prevention and Control, Public Health Agency of Canada (PHAC). <www.phac-aspc.gc.ca/ccdpccpcmc/index_e.html> (Version current at April 11, 2007).

2. Buist AS, Vollmer WM, Sullivan SD, et al. The Burden of Obstructive Lung Disease Initiative (BOLD): Rationale and design. COPD 2005;2:277-83.

3. Laviolette L, Lacasse Y, Doucet M, et al. Chronic obstructive pulmonary disease in women. Can Respir J 2007;14:93-8.

4. Canadian Lung Association. Women \& COPD: A National Report. November 2006. < http://www.lung.ca/_resources/Women_COPD_ Report_2006.pdf> (Version current at May 4, 2007).

5. Lacasse Y, Goldstein R, Lasserson TJ, Martin S. Pulmonary rehabilitation for chronic obstructive pulmonary disease. Cochrane Database Syst Rev 2006;(4):CD003793. 


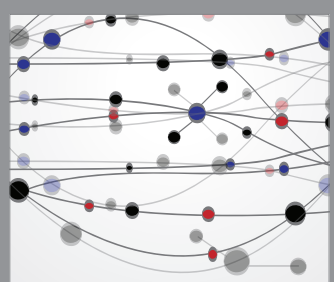

The Scientific World Journal
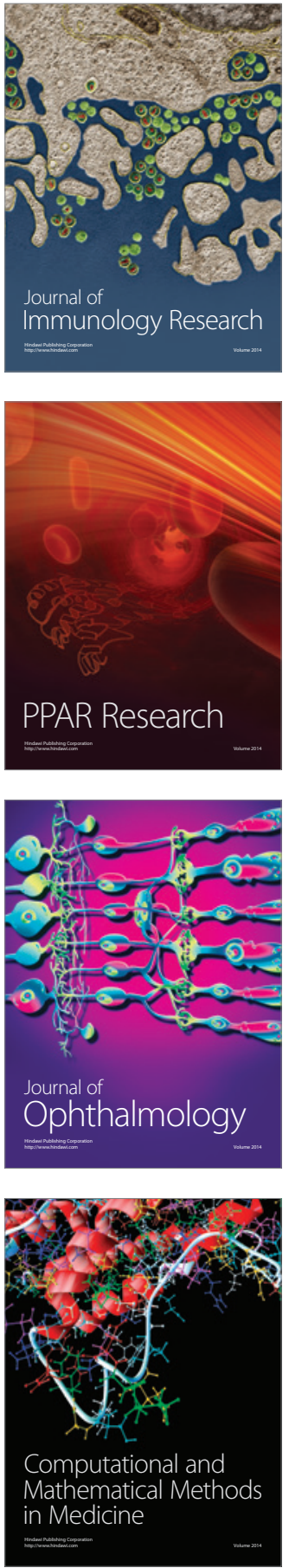

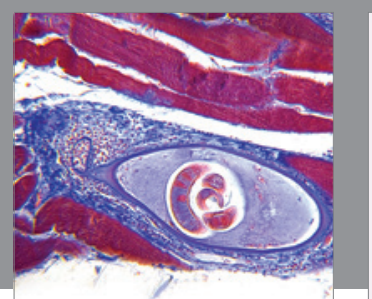

Gastroenterology Research and Practice

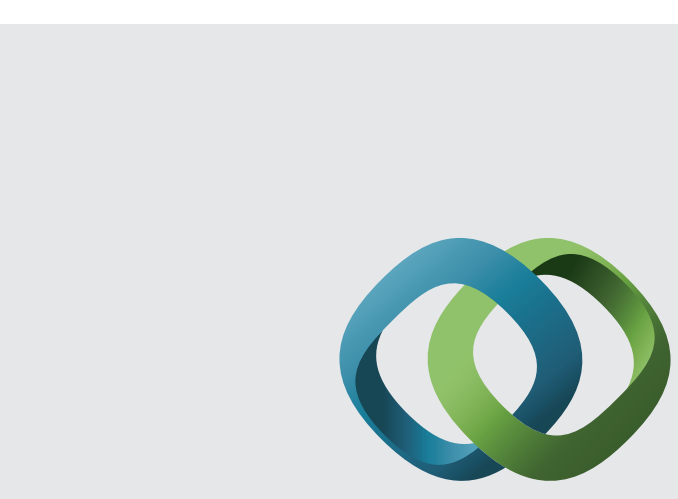

\section{Hindawi}

Submit your manuscripts at

http://www.hindawi.com
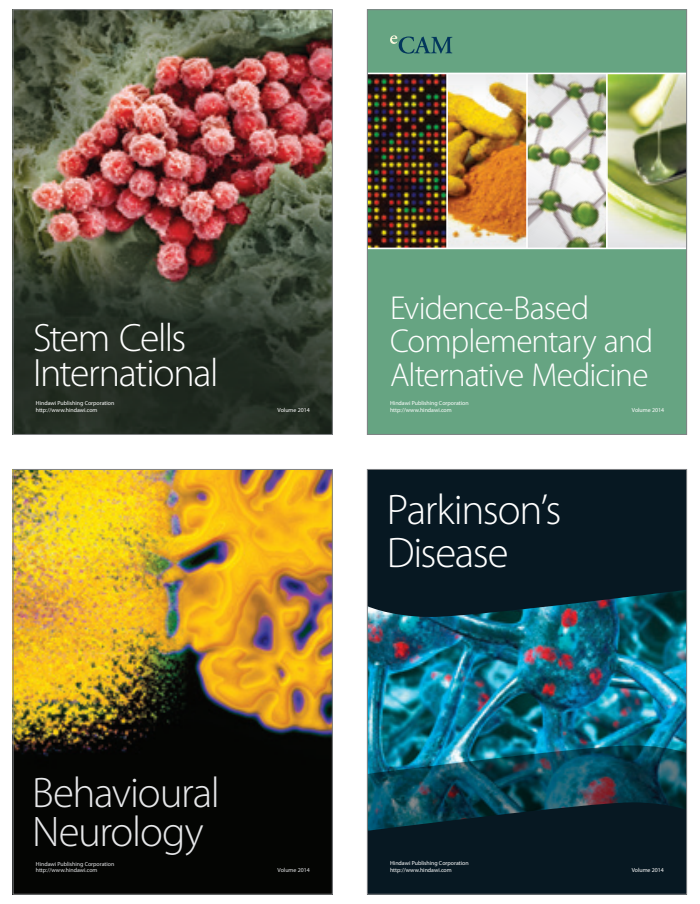
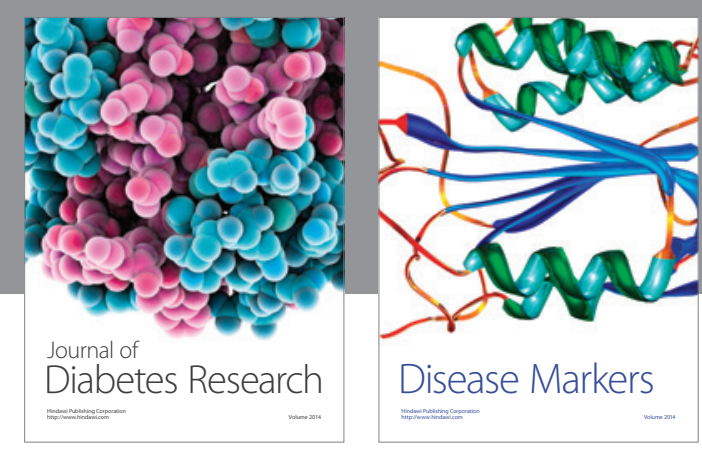

Disease Markers
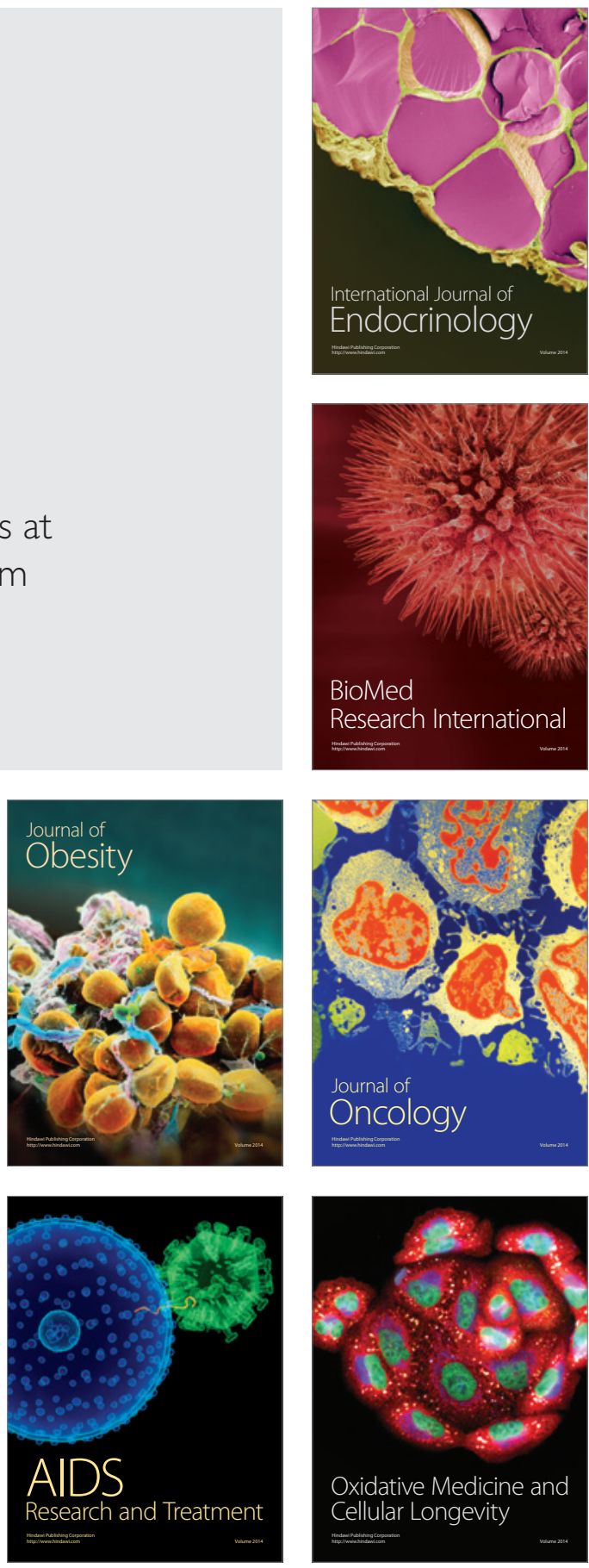